\title{
The ecology and evolution of the Monito del monte, a relict species from the southern South America temperate forests
}

\author{
Francisco Fonturbel ${ }^{1}$, Marcela Franco ${ }^{2}$, Francisco Bozinovic ${ }^{3}$, Julian Quintero-Galvis ${ }^{4}$, \\ Carlos Mejias ${ }^{5}$, Guillermo Amico ${ }^{6}$, María Soledad Vasquez ${ }^{6}$, Pablo Sabat ${ }^{7}$, Juan Carlos \\ Sanchez-Hernández ${ }^{8}$, David Watson ${ }^{9}$, Pablo Saenz-Agudelo ${ }^{5}$, and Roberto Nespolo ${ }^{4}$ \\ ${ }^{1}$ Pontificia Universidad Católica de Valparaíso \\ ${ }^{2}$ Universidad de Ibagué \\ ${ }^{3}$ universidad catolica de chile \\ ${ }^{4}$ Universidad Austral de Chile \\ ${ }^{5}$ El Instituto de Ciencias Ambientales y Evolutivas \\ ${ }^{6}$ Universidad Nacional del Comahue \\ ${ }^{7}$ Universidad de Chile \\ ${ }^{8}$ Universidad de Castilla-La Mancha \\ ${ }^{9}$ Charles Sturt University
}

November 25, 2021

\begin{abstract}
The arboreal marsupial Monito del Monte (genus Dromiciops, with two recognized species) is a paradigmatic mammal. It is the sole living representative of the order Microbiotheria, the ancestor lineage of Australian marsupials. Also, this marsupial is the unique frugivorous mammal in the temperate rainforest, being the main seed disperser of several endemic plants of this ecosystem, thus acting as keystone species. Dromiciops is also one of the few hibernating mammals in South America, spending half of the year in a physiological dormancy where metabolism is reduced to $10 \%$ of normal levels. This capacity to reduce energy expenditure in winter contrasts with the enormous energy turnover rate they experience in spring and summer. The unique life-history strategies of this living Microbiotheria, characterized by an alternation of life in the slow and fast lanes, putatively represent ancestral traits that permitted these cold-adapted mammals to survive in this environment. Here we describe the ecological role of this emblematic marsupial, summarizing the ecophysiology of hibernation and sociality, actualized phylogeographic relationships, reproductive cycle, trophic relationships, mutualisms, conservation and threats. This marsupial shows high densities, despite presenting slow reproductive rates, a paradox that is explained by the unique characteristics of its three-dimensional habitat. We finally suggest immediate actions to protect these locally abundant but globally threatened species.
\end{abstract}

\section{Introduction: relictual lineages, marsupials andDromiciops}

The discovery of living representatives of groups that were thought long extinct opens a window in time to improve our understanding of their biology, as they represent invaluable material to test evolutionary hypotheses on adaptation. These relict species (sensu Habel, Assman, Schmidtt, \& Avise, 2010) generate an enormous amount of valuable knowledge regarding ecological, morphological, and physiological traits of past lineages, as they could serve as a 'window to the past' that allow us to understand the conditions that allowed them to survive for so long (Habel et al., 2010; Tan, Kelly, \& Jiang, 2013; Yoder et al., 2010). Here we address one of these cases, the relict monito del monte ("little mountain monkeys", with two recognised species,Dromiciops gliroides Thomas 1894 and D. bozinovici D'Elia et al. 2016), an outstanding 
mammal from southern South America. From fossil evidence (Goin \& Abello, 2013) and ancestral habitat reconstruction of present-day marsupials (Mitchell et al., 2014), this marsupial (Dromiciops, hereafter) seems to have retained the ecological niche of its Gondwanan marsupial ancestors.

The ancestors of Marsupialia (crown-clade Metatheria) diverged from placental mammals (crown-clade Eutheria) at least 125 Mya in Laurasia (Bi et al., 2018; Luo, Yuan, Meng, \& Ji, 2011), originating in today's China and spreading to North America, where the earliest evidence of true marsupials is known (O'Leary et al., 2013). Those early mammals remained confined to Laurasia until the late Cretaceous, when they dispersed to Gondwana, following a North America - South America path. About the same time, they suffered particularly dire consequences of the KT extinction in Laurasia, which ultimately drove them to extinction on the supercontinent (Case, Goin, \& Woodburne, 2005; Sanchez-Villagra, 2013). In South America, marsupials thrived and diverged, eventually spreading further south and reaching Antarctica about 65-70 Mya (Mitchell et al., 2014), presumably via dispersal of Microbiotherians (Nilsson et al., 2010; Prevosti, Forasiepi, \& Zimicz, 2013). This order reached Australia through Antarctica and gave origin to Australasian marsupials, which dominated the continent and adjacent islands, occupying much the same ecological niches that placental mammals did in every other continent (Long, Long, Archer, Flannery, \& Hand, 2002; Mitchell et al., 2014).

Today, marsupials are taxonomically less diverse than placental mammals, but their long and often isolated evolutionary history has resulted in a comparable morphological and ecological diversity (Sanchez-Villagra, 2013). Extant marsupials are grouped into three American (Didelphimorphia, Microbiotheria, and Paucituberculata) and four Australasian orders (Dasyuromorphia, Diprotodontia, Notoryctemorphia, and Peramelemorphia). The evolutionary relationships among marsupial orders have long been assessed using a wide range of methods that have often yielded contradictory and intensively debated results. Particularly puzzling is the position and origin of Microbiotheria. In this regard, Szalay (1982) proposed that Microbiotheria is nested within the modern Australasian clade: Australidelphia (Meredith, Westerman, Case, \& Springer, 2008; Nilsson et al., 2010). The revolution of genetic and genomic methods during the last couple of decades has helped to disentangle the topology of the marsupial phylogeny (Eldridge, Beck, Croft, Travouillon, \& Fox, 2019), clearly positioning Dromiciopswithin Australidelphia, the sister group of all living Australasian marsupials (Euaustralidelphia) and confirming the monophyly of the rest of American marsupials (Duchêne et al., 2018; Mitchell et al., 2014).

\section{Updated phylogeographic affinities within Dromiciops}

Dromiciops distribution extends from the Chilean Pacific Coast in the west to the slopes of the Chilean Andes in the east and from the Maule Province at the north $\left(35^{\circ} \mathrm{S}\right)$ to the Palena Province at the South $\left(44^{\circ} \mathrm{S}\right)$ (Mejías et al., 2021; Oda, Rodríguez-Gómez, Fontúrbel, Soto-Gamboa, \& Nespolo, 2019). In Argentina, Dromiciops is distributed along the Andes, from Neuquén to Chubut provinces (Figure 1). A small fraction of these habitats (7\%, according to Martin, 2010) corresponds to the central valley of Chile (shrubland-type or Maulino forest habitats); while the temperate rainforest represents the remaining $93 \%$ of its distribution (Lobos, Charrier, Carrasco, \& Palma, 2005; Martin, 2010; Saavedra \& Simonetti, 2001; Uribe, Chiappe, \& Estades, 2017). In addition to being drier than the typical wet rainforest, the habitats occupied in the Chilean central valley receive more sunlight and have more fruits available during the summer (Fontúrbel, Salazar, \& Medel, 2017a). This distribution is much smaller than the past distribution of Microbiotheria, which encompassed Bolivia, Rio de Janeiro (Middle Palaeocene), Argentinian Patagonia, and the Seymour Island in Antarctica (Hershkovitz, 1999). Such distributional shrinking likely reflects major climatic changes, as the original Microbiotheria distribution (during the Miocene) was dominated by a subtropical-humid climate, similar to the present-day Dromiciopshabitat.

$<$ Figure 1 about here $>$

The first phylogeographic analysis of Dromiciops populations was performed using two mitochondrial genes (Himes, Gallardo, \& Kenagy, 2008), identifying three main clades that displayed geographic structure (northern: clade "A", central: clade "B", and southern: clade "C" clades). Most interestingly, this study reported 
sequence divergence between clades $\mathrm{A}$ and $\mathrm{C}$ of $11.3 \%, 15.1 \%$ between $\mathrm{A}$ and $\mathrm{B}$, and $8.2 \%$ between $\mathrm{B}$ and C, markedly differentiated northern and southern clades later confirmed by Valladares-Gómez et al. (2019) using microsatellite markers. According to Himes et al. (2008), Dromiciops populations could have diverged in the Quaternary (1-1.8 Myr) before the last glacial maximum ( $20,000 \mathrm{yr}$ ago), but the deep divergence based on mitochondrial DNA suggests that these could be even older and paleontological evidence appears to agree with older divergences. Fossil evidence indicates that Dromiciops may be morphologically indistinguishable with Microbiotherium, a genus that lived between the late Oligocene and early Miocene $(\sim 29-16$ Myr; Goin \& Abello, 2013), which includes at least four extinct species and is considered the sister group ofDromiciops (Figure 2). Therefore, if Dromiciops is as old as these extinct lineages, this would suggest that the whole clade is as old as the Andes mountain range (Charrier, Pinto, \& Rodríguez, 2006), and older than the scission of the Chiloé island (ca. 10,000 years ago; Watters \& Fleming, 1972). This would explain the similarities between insular and continental populations and between Argentinean and Chilean populations. The time-calibrated phylogenetic reconstruction of these clades provided recently by Quintero-Galvis et al. (2021) confirmed the paleontological dating of Goin and Abello (2013) and the Miocene origin of the genus.

$<$ Figure 2 about here $>$

The pronounced differentiation of Dromiciops north-south populations together with the important morphological differentiation observed across this range have even inspired the proposition of newDromiciops species (D'Elía, Hurtado, \& D'Anatro, 2016). This idea, however, sparked an immediate debate based on species delimitation criteria, morphological comparisons, and genetic evidence (Martin, 2018; Valladares-Gómez, CelisDiez, Palma, \& Manríquez, 2017). Two subsequent studies (Suárez-Villota et al., 2018; Valladares-Gómez et al., 2019) contributed new genetic data and confirmed the existence of the "Northern" and "Southern" clusters of Dromiciops, but differentiation between these groups was not sufficient to warrant recognition as different species. Still, these studies covered a small percentage of this species large $(\sim 1200 \mathrm{~km})$ geographic range. The most complete geographic sampling of Dromiciopspopulations to date was provided by Quintero-Galvis et al. (2021), who resolved genetic distances for 31 localities covering the whole geographic range for the genus. Using two mtDNA and four nuclear genes, these authors proposed four clades, being the northernmost clade different enough from the other three to be considered as a different species (Dromiciops bozinovici). Another study by the same authors, using RAD sequencing (1856 variant SNPs), confirmed these results and proposed that the clade "C", defined by D'Elía et al. (2016) as D. mondaca, to be redefined as a subspecies of $D$. gliroides (Quintero-Galvis et al., 2022).

Phenotypically, the two Dromiciops species differ mainly in the fur coloration, and the size of muzzle and ears. In general, D. bozinovici has fur that is lighter in coloration and shorter muzzle and ears than $D$. gliroides (see Figure 3). Behaviorally, D. bozinovici appears to have lower activity levels and reactivity to human presence and perhaps lower resting metabolism (RFN, personal observation) (Mejías et al., 2021). Both species are small (20-30 g, $110 \mathrm{~mm}$ snout-vent length) arboreal mammals ( ${ }^{\sim} 30 \mathrm{~g}, 110 \mathrm{~mm}$ snout-vent length), with broad carnivorous-frugivorous habits (Vazquez, Rodríguez-Cabal, Gonzalez, Pacheco, \& Amico, 2018; Vazquez, Zamora-Nasca, Rodriguez-Cabal, \& Amico, 2021), social, sexually non-dimorphic, and are found on trees as high $30 \mathrm{~m}$ high in mature broadleaf forests (Godoy-Güinao, Díaz, \& Celis-Diez, 2018). As with other marsupials, they accumulate fat reserves in the body and tail, which is also prehensile. Dromiciops individuals are well adapted to arboreal life; they have opposable thumbs on all four limbs, exhibiting great precision and agility when they move through the canopy. They can run vertically up the bark of the Nothofagus at speeds of up to $1 \mathrm{~m} / \mathrm{s}$ and can leap with enormous precision between distant branches up to one meter far (Balazote-Oliver, Amico, Rivarola, \& Morales, 2017; Mejías et al., 2021). This is attained by visual and cerebellar adaptations to discriminate distances in absolute darkness (di Virgilio, Amico, \& Morales, 2014; Gurovich \& Ashwell, 2020), and most likely given their Australidelphia trichromate condition (colour vision in the ultraviolet-infrared spectrum; (Arrese, Hart, Thomas, Beazley, \& Shand, 2002). The recent discovery that Dromiciopsfur fluoresce pink with UV light supports this idea. This is also possible to adapt for inter-individual recognition in the dark (Y. Gurovich and R. Nespolo, personal observation). Thus, it is highly probable that Dromiciops can identify the colour of the fruits in almost complete darkness, and in turn, detect each other with visible colouration patterns in the ultraviolet zone, as in platypuses and 
springhares (Anich et al., 2021; Olson et al., 2021).

$<$ Figure 3 about here $>$

\section{The "conservative" reproduction of Dromiciops}

Although the basic biology of Dromiciops has been historically considered poorly known, this situation has drastically changed in the last decades, as several populations have been studied in detail by Latin American researchers (e.g., Balazote-Oliver et al., 2017; Celis-Diez et al., 2012; Fontúrbel, Franco, Rodríguez-Cabal, Rivarola, \& Amico, 2012; Franco, Quijano, \& Soto-Gamboa, 2011; Kelt, Meserve, Patterson, \& Lang, 1999; Meserve, 1981; Meserve, Lang, \& Patterson, 1988; Patterson, Meserve, \& Lang, 1989). Inappropriate capture methods (Fontúrbel, 2010; Fontúrbel \& Jiménez, 2009), but also lack of knowledge about its seasonal activity patterns led to a large underestimation of its densities (Fontúrbel \& Jiménez, 2011; Franco et al., 2011; Nespolo, Verdugo, Cortes, \& Bacigalupe, 2010). For example, captive D. gliroides individuals seem to be more active during summer than during other seasons (Aizen, 2003; Kelt \& Martínez, 1989), but only recently, several authors have studied Dromiciopsactivity in the field. For instance, Fontúrbel, Candia, and Botto-Mahan (2014) found that this species presents a nocturnal activity (from 19:00 h to 07:00 h), with a significant monthly variation related to resource abundance and distribution, closely related to fleshy fruit availability (di Virgilio et al., 2014; Fontúrbel, Salazar, \& Medel, 2017b).

Historical descriptions (Hershkovitz, 1999; Mann, 1978; Muñoz-Pedreros, Lang, Bretos, \& Meserve, 2005) indicate that Dromiciops is relatively long-lived, with reports of 5-6 years-old individuals captured in the field (Balazote-Oliver et al., 2017). According to Muñoz-Pedreros et al. (2005), D. gliroides reproductive cycle is divided into seven stages. They attain sexual maturity at the second year of age and start reproducing in August-September (stage I: pair formation), then producing 1-4 pups (females have four nipples) that develop in the uterus for about a month (stage II: intra-uterine development), and approximately in early November they migrate to the marsupium (stage III: parturition) and start lactation (stage IV: intra-marsupium development). Most Australian marsupials are characterised by secreting milk of different compositions from different mammary glands, in close concordance to the development stage of the young (Pharo, 2019; Renfree, 1981), which is unknown for this marsupial. During the austral summer (December-January), pouched young abandon the marsupium for short exploratory excursions. However, they do not stop suckling and use the nest as a centre for home-range activities (stage V: extra-marsupium development) (Figure 4). Finally, juveniles join family excursions during February (stage VI: nocturnal family excursions), coinciding with the elevated trapping success usually reported. Then, juveniles become independent in March (Stage VII: juvenile independence) and start preparing for hibernation (see below). A summary of Dromiciops annual cycle is presented in Figure 5.

$<$ Figures 4 and 5 about here $>$

This extended Dromiciops breeding (i.e., 20 days of gestation and 70 days lactating), which is also energetically very extenuating and energy consuming, is combined with a low reproductive output. For instance, a female Dromiciops individual can produce a maximum of four offspring in a single reproductive event each year and become fertile at the second year. This represents a reproductive output of two new individuals per year (Nespolo et al., 2022). In comparison, opossums (Thylamys elegans, for instance, which is sympatric with $D$. bozinovici in its northern distribution range) produce up to 16 individuals per reproductive event, which attain sexual maturity at the first year. This translates into a (a maximum) reproductive output of 16 individuals per year, eight times the value for Dromiciops (assuming only one breeding period per year). Similarly, the poorly known sympatric marsupial Rhyncholestes raphanurus (Caenolestidae) has been described to have continuous reproduction at any moment of the year, with a maximum litter size of seven young individuals (Iriarte, 2008). Reproduction in Dromiciops is followed by a fattening period in which animals forage frenetically to gain weight for hibernation, which starts in autumn. The peak of energy expenditure occurs during lactation, which is the longest recorded in marsupials and in Dromiciops extends from December to January. To compensate for the high energy expenditure of this extravagant way of life, Dromiciops must reduce energy expenditure in the cold period, which is achieved by hibernation. 


\section{Daily, seasonal, and "hot" torpor in Dromiciops}

The seasonal regulation of energy balance is a key concept in mammalian life histories (Harvey, Pagel, \& Rees, 1991), and hibernation - a distinctive characteristic of Dromiciops — represents the evolution of "slow" life histories (Turbill, Bieber, \& Ruf, 2011).Dromiciops spend six months a year in this lethargic condition, constraining the activity period to spring and summer (Figure 5). In eutherian hibernators, there is a marked cycle of adiposity, where animals accumulate fat during summer to be consumed during hibernation, without ingesting any food during this period (Humphries, Kramer, \& Thomas, 2003; Humphries, Thomas, \& Speakman, 2002; Toien et al., 2011). In Dromiciops, this cycle is unclear as they ingest food whenever they find it, which can happen even during interbout arousals when hibernating (Franco, Contreras, Place, Bozinovic, \& Nespolo, 2017; Nespolo et al., 2020). In this section, we discuss distinctive aspects of seasonality and energetics of $D$. gliroides : its capacity for daily, seasonal torpor and aestivation (torpor in response to hot and dry conditions).

Hibernation (also known as "seasonal torpor"; Geiser \& Ruf, 1995) was first described in placental mammals of the northern hemisphere (e.g., squirrels, marmots, hamsters, bears; Melvin \& Andrews, 2009), where a clear pattern of seasonal metabolic depression in autumn and winter is distinguished from continuous periods of activity in spring and summer (Geiser, Currie, O'Shea, \& Hiebert, 2014; Heldmaier, Ortmann, \& Elvert, 2004). This is functionally different from daily torpor, which consists of short and shallow bouts of metabolic depression of a few hours that occur at any moment of the year and is characteristic of several bat and marsupial species (Geiser, 2013; Ruf \& Geiser, 2015).Dromiciops seems to do both, as was confirmed recently by a set of experiments under semi-natural enclosures, indicating that in winter, animals experience seasonal torpor with multiday torpor episodes lasting 5 to 10 days, which together represents a net energy savings of $90 \%$ compared to animals that did not hibernate (Mejías, Sabat, Franco, Bozinovic, \& Nespolo, 2022). This complemented older studies indicating that Dromiciops experiences a dynamic form of torpor, including daily torpor of a few hours, at any moment of the year, whenever food or water is scarce (Nespolo, Fontúrbel, et al., 2021). A novel aspect ofDromiciops torpor was recently revealed when animals under hot torpor (also known as aestivation: metabolic depression under hot and dry conditions) were discovered in the field (Nespolo, Fontúrbel, et al., 2021). These authors described torpor in summer, with temperatures were above $25^{\circ} \mathrm{C}$ and water was scarce. The same study described torpor in females with pups at the marsupium (pups were also in torpor, see Fig 2 in Nespolo, Fontúrbel, et al., 2021). When entering into winter torpor, animals experience a metabolic shut-down followed by passive cooling, to a limit of about $-0.5^{\circ} \mathrm{C}$ in the tissues, and then they start thermoregulating in torpor in order to avoid freezing (Mejías et al., 2022; Nespolo, Fontúrbel, et al., 2021). The whole transition from normothermia to torpor lasts 4-6 hours (Cortés, Franco, Moreno-Gómez, Barrientos, \& Nespolo, 2014), and happens in the nest, normally in groups of two to five individuals (Franco et al., 2011; Nespolo, Fontúrbel, et al., 2021), but arousal can be as rapid as in 30-150 minutes, depending on ambient temperature (Mejías et al., 2022; Nespolo, Fontúrbel, et al., 2021). These costly rewarming events are bursts of aerobic activity that could account for $25 \%$ of the energy consumed during hibernation (Mejías et al., 2022). Rewarming during hibernation have a typical frequency in winter of about twice a month (Nespolo, Fontúrbel, et al., 2021; Nespolo, Mejías, et al., 2021), which explains why long-term energy savings during hibernation (90\%) are lower than the energy reduction estimated from a single torpor bout $(96 \%$, see Mejías et al., 2022). The extreme capacity to endure underzero temperatures of hibernating Dromiciops explains its presence in high Andean locations such as Altos de Lircay at the northern edge of the distribution (Mejías et al., 2021), Llao Llao in Argentina (RodriguezCabal, Amico, Novaro, \& Aizen, 2008) or Futaleufú at the southern limit (Oda et al., 2019). The seasonal cycle of hibernation-activity of Dromiciops define an annual energy budget with profits and loss, that the animal modulates precisely in order to give an overall positive balance (Figure 6).

$<$ Figure 6 about here $>$

\section{Social thermoregulation and communal nesting}

Extensive fieldwork has shown that D. gliroides nests and hibernates communally, in tree holes or bamboo stems but, in some cases, nesting occurs with animals individually curled up instead of grouped in the nest 
(Figure 7a). Nests built by $D$. gliroides are spherical, with a single entrance, built with plant materials from Chusqueaspp. leaves, Hymenophyllum spp. ferns, and lined with many moss species (Figure 7b). Occasionally, nests are used more than once, although they prefer to build new ones. Based on these observations, Franco et al. (2012; 2011) and Celis-Diez et al. (2012) showed that communal nesting is common in D. gliroides using nest-boxes in two localities of southern Chile (near Valdivia and in Chiloe), with a mean of 2.3 animals per nesting box. Monitoring of nest boxes suggested that D. gliroides is resident throughout the year and uses torpor during cold seasons. Ageing negatively correlates with $D$. gliroides communal nesting, as juveniles usually nest in groups ( $17 \%$ are found nesting solitary), whereas adults usually nest solitary ( $83 \%$ found nesting solitary; Celis-Diez et al., 2012). Neither sex nor body mass seems to influence communal nesting in D. gliroides . Several Australian marsupials (Baker \& Dickman, 2018), American rodents (Arnold, 1988; Boyles, Storm, \& Brack, 2008; Bustamante, Nespolo, Rezende, \& Bozinovic, 2002; Edelman \& Koprowski, 2007; Schradin, Schubert, \& Pillay, 2006; Viñals, Bertolino, \& Gil-Delgado, 2017; Wilson, O'Riain, Hetem, Fuller, \& Fick, 2010), and Neotropical bats (Roverud \& Chappell, 1991) obtain significant energetic savings by hibernating in groups (Gilbert et al., 2010). This phenomenon remains little explored in D. gliroides . Preliminary laboratory measurements indicate, however, that grouped individuals do not benefit from thermoregulatory savings during torpor (Franco et al., 2012), which suggests that for D. gliroides, the energetic benefits of communal nesting are secondary to the benefits of sociality itself (Boix-Hinzen \& Lovegrove, 1998; Ebensperger, 2001; Schradin et al., 2006). These observations were confirmed by recent mesocosms experiments performed in hibernating individuals in the field using thermographic images, which suggest that clustered D. gliroides do not conserve heat better than animals hibernating in isolation (Nespolo, Fontúrbel, et al., 2021; Figure 7c). These individuals were not related, discards the idea that communal nesting is driven by kin relatedness or parental care (Franco et al., 2011; see Figure 7d).

$<$ Figure 7 about here $>$

\section{The "all-purpose" trophic strategy of Dromiciops}

The common name "monito del monte" refers to the arboreal habits of this marsupial, which includes opposable thumbs and a prehensile tail, resembling a small primate. They move relatively long distances (home range: $1.6 \pm 0.6$ ha) (Fontúrbel et al., 2012), across the canopy, reaching 30 meters of height (GodoyGüinao et al., 2018), and speeds of $1 \mathrm{~m} / \mathrm{s}(3.7 \mathrm{~km} / \mathrm{h}$, see Mejías et al., 2021), which for a 20-30 g mammal is extremely fast (e.g., Djawdan \& Garland, 1988). Their agility in forest canopies permits these animals to forage efficiently on a variety of food items, for which qualitative descriptions exist, based on faecal analysis and laboratory preference trials (Amico, Rodríguez-Cabal, \& Aizen, 2009; Celis-Diez et al., 2012; Cortés, Franco, Sabat, Quijano, \& Nespolo, 2011; di Virgilio et al., 2014; Meserve et al., 1988; Quijano, 2008). These studies have shown that D. gliroides does not appear to be selective (contrarily to other mammals, which select food items with specific nutrient composition, see Torres-Contreras \& Bozinovic, 1997; Woods, 2009), but rather opportunistic (i.e., dietary composition follows environmental availability, see Bozinovic, Muñoz, Naya, \& Cruz-Neto, 2007; Cortés et al., 2011; Quijano, 2008). However,Dromiciops cannot fulfil its nutritional requirements only from fruits or insects. Contrarily, it needs a mixed diet of fruits and insects to maintain a healthy body condition and a proper energy balance (Cortés et al., 2011). It is well established that differences in the digestive physiology of vertebrates reflect the historic levels of specific substrates of the natural diets, linking digestive enzyme activity, dietary flexibility, and digestive plasticity in an evolutionary context (Ramirez-Otarola, Narvaez, \& Sabat, 2011; Sabat, Lagos, \& Bozinovic, 1999; Sabat, Novoa, Bozinovic, \& del Rio, 1998). Therefore, the digestive physiology of D. gliroides supports the hypothesis that digestive capabilities are a necessary — but not an essential - component for explaining dietary selection (Bozinovic \& Martínez del Río, 1996; Cortés et al., 2011; Silva, Jaksic, \& Bozinovic, 2004; Veloso \& Bozinovic, 2000).

Fruit availability represents a strong driver of Dromiciopsdietary habits. They select individual fruits according to their size and colour, exerting important selective forces on plant populations (Fontúrbel \& Medel, 2017), performing long foraging trips to disturbed forest stands to consume fleshy fruits (Amico, RodríguezCabal, \& Aizen, 2011; di Virgilio et al., 2014; Mora \& Soto-Gamboa, 2011; Salazar \& Fontúrbel, 2016). In 
fact, Dromiciops consumes fruits from at least 16 species of shrubs, trees, vines, and particularly from the hemiparasite mistletoe Tristerix corymbosus (see Table 1 in Amico et al., 2009). Then, considering the assorted nutrient content onDromiciops ' diet, an interesting set of questions arises, such as how these requirements vary among individuals at different ontogenetic stages (Maldonado et al., 2016), or if they exhibit ontogenetic trophic niche shifts as a logic outcome (Araujo, Bolnick, \& Layman, 2011; Schoener, 1971). Furthermore, considering that male and female marsupials invest energy differently during the reproductive period, ecological sexual dimorphism in diet selection could be expected (Araujo et al., 2011; Schoener, 1971). This is an interesting avenue that can be explored, for instance, using the most recent technologies in stable isotope analysis (Maldonado, Bozinovic, Newsome, \& Sabat, 2017).

\section{Frugivory: A Retained Characteristic of Microbiotheria?}

The mutualistic relationships between Dromiciops and several endemic plants can be traced back in time to their ancestors. These facts furnish fascinating ideas about the trophic habits of past Microbiotheriids and their eco-evolutionary relationships with the temperate flora of southern South America, which may have coevolved during millions of years. Highly specific and asymmetric (i.e., uneven dependence between the plant and the animal) interactions have appeared, such as the seed dispersal relationships between Dromiciops and the hemiparasitic mistletoe Tristerix corymbosus (Aizen, 2003; Amico \& Aizen, 2000).

Recent work suggests an inter-dependence between Dromiciops and Tristerix, which may also reflect an ancient association between microbiotheriids and mistletoes. Successive phylogenetic reconstructions have pushed the origin of mistletoes back further in time (Liu et al., 2018; Nickrent, Malécot, Vidal-Russell, \& Der, 2010), with the growth habit now estimated to have transitioned from root parasite to aerial parasite in the Loranthaceae during the early Eocene (approximately 50 million years ago). Based on fossil reconstructions and the modern-day distribution of lineages on either side of this transition, it is estimated that the shift from understorey up to the canopy occurred in western Gondwanaland. This time is 20 to 30 million years prior to the origin of the modern frugivorous birds, the main dispersers of Loranthaceae mistletoes today (Liu et al., 2018). This temporal mismatch between the origins of mistletoes and their seed dispersers has been previously noted, as early Microbiotheriids are invoked as the most probable agents of mistletoe dispersal prior to the diversification of songbirds (Amico \& Aizen, 2000; Restrepo, Sargent, Levey, \& Watson, 2002). Recently, this idea has been taken one step further by Watson (2020), who suggested Microbiotheriids may have been indeed the selective agents responsible for the transition within Loranthaceae from root-parasitic shrubs to stem-parasitic mistletoes. By consuming fruits from understorey shrubs and dispersing them up to the canopy,Dromiciops ancestors catalysed the switch in growth habit to the upper canopy, where transitional forms likely parasitised the roots of vascular epiphytes like the present-day Gaiadendron (Restrepo et al., 2002).

\section{Ecological Role and Interactions}

Seed dispersal by Didelphid marsupials has been widely reported in tropical forests (Cáceres, 2002; Santori, De Moraes, \& Cerqueira, 1995, 2004). A few marsupial species have also been involved in seed dispersal interactions in Australia (Ballardie \& Whelan, 1986; Bass, 1990; Dennis, 2003) and even in New Zealand, where they are non-native (Dungan, O'Cain, Lopez, \& Norton, 2002; Williams, Karl, Bannister, \& Lee, 2000). The high incidence of frugivory and seed dispersal onDromiciops is remarkable among American and Australian marsupials, posing interesting questions about the coevolutionary processes that shaped the temperate rainforest's native flora. Recent work in Madagascar has uncovered comparable inter-dependence between mistletoes and mouse lemurs (Cheirogaleidae). As with Dromiciops, these small mammals are active throughout the canopy and act as principal dispersers of mistletoe seeds in their habitats. They also undergo prolonged periods of torpor/hibernation during periods of low resource availability (Génin \& Rambeloarivony, 2018 and references therein).

Mistletoes are shrubby stem-parasitic plants with more than 1600 species for which dispersal represents a critical link in their life cycle (Mathiasen, Nickrent, Shaw, \& Watson, 2008; Nickrent et al., 2010; Norton \& Carpenter, 1998). Most of these plants depend on animal vectors for transporting their seeds from the 
parent plant to the branches of competent host plants. Mistletoes produce ripe green fruits within the South American temperate rainforests, which are not easily detected by birds (as they depend on chromatic contrast). Nevertheless,Dromiciops are nocturnal and locate their food primarily by scent, hearing, and vision (Amico et al., 2011). Together with their capacity for colour vision at the ultraviolet-infrared spectrum (the trichromacy, discussed before), permit them to be excellent foragers at night. Seed passage through Dromiciops digestive tract is critical for T. corymbosus germination (Amico \& Aizen, 2000; Amico, Sasal, Vidal-Russell, Aizen, \& Morales, 2017), as revealed by experimental germination trials (close to $100 \%$ of successful germination; Amico et al., 2017). Furthermore, seed establishment is strongly favoured by Dromiciops' climbing behaviour, defecating seeds within suitable hosts and at adequate branch sizes (Amico et al., 2017), in turn impacting positively on the mistletoe regeneration rate in the forest (Amico et al., 2017; García, Rodríguez-Cabal, \& Amico, 2009). Consequently, T. corymbosus abundance and distribution is spatially correlated with the presence of Dromiciops , both at different spatial scales (Fontúrbel et al., 2017a; García et al., 2009; Rodríguez-Cabal \& Branch, 2011).

The cascade of ecological services provided by $D$. gliroidesextends to the whole forest community in different ways, one being the important relationship between the mistletoe T. corymbosus and the hummingbird Sephanoides sephaniodes for pollination (Aizen, 2003). This hummingbird is responsible for pollinating several species of the highly endemic woody flora in this biome (Aizen, Vázquez, \& Smith-Ramírez, 2002; Armesto, León-Lobos, \& Arroyo, 1996). In contrast to most temperate forests where hummingbirds migrate to warmer climates in winter, this species is resident (Aizen \& Ezcurra, 1998) when T. corymbosus is present, serving as its principal food during this period. Hence, the mutualistic relationship between the marsupial and the mistletoe determines the distribution of the plant and may have broader evolutionary consequences. The marsupial might have allowed the mistletoe T. corymbosus to retain green colouration in mature fruits, a condition to which it is preadapted by a slower ripening process in temperate forest populations (Amico et al., 2011).

\section{Conservation, Threats, and Future Trends}

As an arboreal marsupial, a key issue for Dromiciops persistence is its dependence on forest habitats with certain structural features (Fontúrbel, Candia, Salazar, et al., 2014). Even though the IUCN updated its threat category from Vulnerable to Near Threatened in 2011, the main problem persists: habitat loss. The southern South America temperate rainforests are rapidly being cleared due to land-use change (Echeverría et al., 2006; 2007). Therefore, suitable habitat for $D$. gliroidesis not only reduced but also becoming increasingly fragmented and degraded. Habitat fragmentation has a negative effect onDromiciops abundance, causing local extinction in small fragments (Rodríguez-Cabal, Aizen, \& Novaro, 2007), and collapsing seed dispersal services (Amico \& Aizen, 2000; Amico et al., 2011). Fragmentation threatens this marsupial as it is unable to disperse through open habitats (e.g., pastureland), remaining confined to the extant forest fragments (Fontúrbel, Silva-Rodríguez, Cárdenas, \& Jiménez, 2010).

Although some authors have recorded D. gliroides in exotic plantations (Fontúrbel, Candia, \& Botto-Mahan, 2014; Uribe et al., 2017), a fragment of a native forest was always found in the vicinity, where they maintain their nesting sites (Salazar \& Fontúrbel, 2016). As a strict arboreal mammal, D. gliroides require a dense forest with a complex three-dimensional architecture covering the whole vertical matrix. In fact, the discovery of Dromiciops as high as $30 \mathrm{~m}$ above ground in the canopy using camera traps were expected but difficult to document precisely (Godoy-Güinao et al., 2018; Tejo \& Fontúrbel, 2019). Forest requirements, together with frugivorous habits, configure a strong dependence on a very special kind of ecosystem characterised by the combined presence of the native bamboo (Chusquea spp.) and Nothofagus spp. and Myrtaceae plants (Rodríguez-Cabal \& Branch, 2011), influencing the particularities ofDromiciops nest. Nests are considered part of an organism's 'extended phenotype' (Rubalcaba, Polo, Maia, Rubenstein, \& Veiga, 2016), imprinted by the same combination of environmental and genetic factors of standard phenotypic variation. In the case of Microbiotheria, several lines of evidence suggest that the nest is fundamental for their survival (Franco, Contreras, \& Nespolo, 2013; Hershkovitz, 1999; Honorato et al., 2016). Dromiciops nests are built as an oval cavity covered by a scaffold of tightly interwoven bamboo leaves combined with mosses and Hymenophyllum 
ferns (Celis-Diez et al., 2012). This structure is impermeable and well insulated. Some authors have also attributed antimicrobial properties to it (Honorato et al., 2016), as its thick structure and the acid pH of the Chusqueaspp. leaves may protect from predators and have a biocidal effect against parasites and pathogens.

Since D. gliroides distribution and abundance are influenced by several factors (particularly bamboo and mistletoe abundance; Rodríguez-Cabal \& Branch, 2011), transformed habitats can give valuable insights on D. gliroides persistence probabilities in a changing world. A telemetry-based study (Salazar \& Fontúrbel, 2016) showed that $D$. gliroides movement behaviour was similar between native and transformed habitats (and consistent with other locations reported by Fontúrbel et al., 2012). However, its occurrence in transformed habitats was mainly determined by neighbouring native remnants in the landscape where $D$. gliroides nests. Animals loaf in these native patches during the day, but perform foraging trips to abandoned plantations during the night (Salazar \& Fontúrbel, 2016), attracted by many shade-intolerant plant species that provide abundant fruits, such asAristotelia chilensis , Rhaphithamnus spinosus , or Ugni molinae (Fontúrbel et al., 2017a).

Another major threat to this species is climate change. Given its hibernating habit, even a slight increase in winter temperatures can drastically affect them. In this case, heterothermy is Dromiciopsnormal condition, and it needs to hibernate during the winter to survive with the energy reserved collected during the summer (Nespolo, Mejías, et al., 2021). Thus, climate change emerges as a critical threat to this species as warmer temperatures necessitate extra energy expenditure, resulting in a lower survival probability (Nespolo, Fontúrbel, et al., 2021). Furthermore, severe and prolonged droughts are a consequence of climate change and can cause moisture stress in plants. Such moisture stress causes significant reductions in flower and fruit production (Fontúrbel, Lara, Lobos, \& Little, 2018), indirectly reducingDromiciops energy reserves. Altogether with the destruction of its habitats, climate change may relegate this species and, with it, the entire order to the fossil record if no actions are taken in the short term. Thus, Dromiciops local extinctions may have cascade effects in the community as a result of the loss of the seed dispersal services that this marsupial performs.

\section{Concluding Remarks}

According to the metabolic theory of ecology (Brown, Gillooly, Allen, Savage, \& West, 2004), populations that maintain a sustained (positive) rate of nutrient conversion into new individuals will persist compared to those that do not (Sibly \& Calow, 1986; Sibly \& Hone, 2002). This could be attained either by maximising the annual reproductive rate, which in mammals is represented by small, short-lived species (Shattuck \& Williams, 2010), and in marsupials characterised by the smallest Didelphimorphia (i.e., the "fast" extreme, see Fisher, Owens, \& Johnson, 2001). The "slow pace" marsupial extreme is represented by large herbivorous forms such as Vombatidae and Phalangeridae (Fisher et al., 2001). Hence, the small living Microbiotherids, with a reproductive output of two individuals per year (Nespolo et al., 2022), fall in the "slow" extreme. In terms of the allometric predictions for life histories in marsupials, given by the equation: age at first reproduction $=5.75^{*} \mathrm{M}_{\mathrm{B}}{ }^{0.10}$ provided by Hamilton et al. (2011), a $30 \mathrm{~g}$ marsupial such as Dromiciopsshould have an age of first reproduction of 243 days (but it attains sexual maturity at 720 days). A similar computation for a maximum lifetime $\left(=0.041 * \mathrm{M}_{\mathrm{B}}{ }^{0.20}\right.$, Hamilton et al. (2011) gives 2.5 years (but in Dromiciops, this parameter is above $4-5$ years) (Nespolo et al., 2022). Then, the high observed densities of Dromiciops can only be explained by low mortality and an extended reproductive period during their lifetime, an aberrant lif history which can only be achieved in a complex three-dimensional habitat, such as mature temperate rainforests.

Hershkovitz (1999) proposed that Microbiotheriids' life history is intimately associated with a combination of Nothofagus trees and Chusquea native bamboos (i.e., theChusquea-Nothofagus-Microbiotheria association, $\mathrm{CNF}$ ), which allowed them to build their sophisticated and impermeable nests that, in turn, are fundamental for hibernating in such a humid and cold forest. Thus, (according to Hershkovitz, 1999) what eventually extinguished all other Microbiotheriids was the disruption of the CNF by desertification at the northern edge of their distribution and freezing temperatures at the South (including Antarctica) (Hershkovitz, 1999, p10). Such phylogenetic conservatism (sensu Buckley et al., 2010) of Microbiotheriids niche is consistent with 
the paleontological evidence, which describes the oldest and largest Microbiotheriid known (Woodbounodon case $i$ ) as "a generalised non-microbiotheriid Microbiotherian" that "resembles other frugivorous marsupials" (Goin et al., 2007).

Contemporary reconstructions also suggest that habitat preference is highly conserved across the marsupial phylogeny, as ancestral trait reconstruction of basal marsupial nodes is assigned to wet-closed environments with large posterior probabilities (i.e., rainforests, see Fig. 1 in Mitchell et al., 2014). These observations are also supported by recent evidence suggesting that mutualistic associations of microbiotheriids with aerial mistletoes dates back to the Cretaceous (Liu et al., 2018; Watson, 2020). The ancestral marsupial that colonised Australia from Antarctica was probably little different from the present-day Microbiotheriid, Dromiciops - an arboreal, nest-building, social, omnivorous-frugivorous mammal with adaptations to the cold, seasonal and humid canopy of the rainforest. This generalised all-purpose animal had the potential for adapting and specialising to the new ecological niches opened by the isolation of Australia and would explain the success of colonisation and posterior diversification of Australasian marsupials.

\section{Acknowledgements}

RFN was supported by ANID-FONDECYT project 1180917, FEF was supported by ANID-FONDECYT project 1210166. FB, RFN, and PS acknowledge ANID PIA/BASAL FB0002. JFQG was supported by an ANID PhD fellowship (grant 21160901/2016).

\section{References}

Aizen, M. A. (2003). Influences of animal pollination and seed dispersal on winter flowering in a temperate mistletoe. Ecology, 84 (10), 2613-2627. doi:10.1890/02-0521

Aizen, M. A., \& Ezcurra, C. (1998). High incidence of plant-animal mutualisms in the woody flora of the temperate forest of South America: biogeographical origin and present ecological significance.Ecología Austral, $8,217-236$.

Aizen, M. A., Vázquez, D. P., \& Smith-Ramírez, C. (2002). Historia natural y conservación de los mutualismos planta-animal del bosque templado de Sudamérica austral. Revista Chilena De Historia Natural, 75 , 79-97.

Amico, G. C., \& Aizen, M. A. (2000). Mistletoe seed dispersal by a marsupial. Nature, 408 , 929-930. doi:10.1038/35050170

Amico, G. C., Rodríguez-Cabal, M. A., \& Aizen, M. A. (2009). The potential key seed-dispersing role of the arboreal marsupialDromiciops gliroides . Acta Oecologica-International Journal of Ecology, 35 (1), 8-13. doi:10.1016/j.actao.2008.07.003

Amico, G. C., Rodríguez-Cabal, M. A., \& Aizen, M. A. (2011). Geographic variation in fruit colour is associated with contrasting seed disperser assemblages in a south-Andean mistletoe. Ecography, 34 (2), 318-326. doi:10.1111/j.1600-0587.2010.06459.x

Amico, G. C., Sasal, Y., Vidal-Russell, R., Aizen, M. A., \& Morales, J. M. (2017). Consequences of disperser behaviour for seedling establishment of a mistletoe species. Austral Ecology, 42 (8), 900-907. doi:10.1111/aec.12517

Anich, P. S., Anthony, S., Carlson, M., Gunnelson, A., Kohler, A. M., Martin, J. G., \& Olson, E. R. (2021). Biofluorescence in the platypus (Ornithorhynchus anatinus ). Mammalia, 85 (2), 179-181. doi:10.1515/mammalia-2020-0027

Araujo, M. S., Bolnick, D. I., \& Layman, C. A. (2011). The ecological causes of individual specialisation. Ecology Letters, 14 (9), 948-958. doi:10.1111/j.1461-0248.2011.01662.x

Armesto, J. J., León-Lobos, P., \& Arroyo, M. T. K. (1996). Los bosques templados del sur de Chile: una isla biogeográfica. In J. J. Armesto, C. Villagrán, \& M. T. K. Arroyo (Eds.), Ecología de los bosques nativos de Chile (pp. 23-28). Santiago de Chile: Editorial Universitaria. 
Arnold, W. (1988). Social thermoregulation during hibernation in Alpine marmots (Marmota marmota). Journal of Comparative Physiology B-Biochemical Systemic and Environmental Physiology, 158 (2), 151-156. doi:10.1007/Bf01075828

Arrese, C. A., Hart, N. S., Thomas, N., Beazley, L. D., \& Shand, J. (2002). Trichromacy in Australian marsupials. Current Biology, 12 (8), 657-660. doi:10.1016/S0960-9822(02)00772-8

Baker, A., \& Dickman, C. (2018). Secret lives of carnivorous marsupials . Clayton South: CSIRO Publishing.

Balazote-Oliver, A., Amico, G. C., Rivarola, M. D., \& Morales, J. M. (2017). Population dynamics of Dromiciops gliroides (Microbiotheriidae) in an austral temperate forest. Journal of Mammalogy, 98 (4), 1179-1184. doi:10.1093/jmammal/gyx051

Ballardie, R. T., \& Whelan, R. J. (1986). Masting, seed dispersal and seed predation in the cycad Macrozamia communis . Oecologia, 70 (1), 100-105. doi:10.1007/Bf00377116

Bass, D. A. (1990). Dispersal of an introduced shrub (Crataegus monogyna) by the brush-tailed possum (Trichosurus vulpecula ).Australian Journal of Ecology, 15 (2), 227-229. doi:10.1111/j.1442-9993.1990.tb01531.x

Bi, S. D., Zheng, X. T., Wang, X. L., Cignetti, N. E., Yang, S. L., \& Wible, J. R. (2018). An Early Cretaceous eutherian and the placental-marsupial dichotomy. Nature, 558 (7710), 390-+. doi:10.1038/s41586-018-0210-3

Boix-Hinzen, C., \& Lovegrove, B. G. (1998). Circadian metabolic and thermoregulatory patterns of redbilled woodhoopoes (Phoeniculus purpureus ): the influence of huddling. Journal of Zoology, 244, 33-41. doi:10.1111/j.1469-7998.1998.tb00004.x

Boyles, J. G., Storm, J. J., \& Brack, V. (2008). Thermal benefits of clustering during hibernation: a field test of competing hypotheses on Myotis sodalis . Functional Ecology, 22 (4), 632-636. doi:10.1111/j.13652435.2008.01423.x

Bozinovic, F., \& Martínez del Río, C. (1996). Animals eat what they should not: Why do they reject our foraging models? Revista Chilena De Historia Natural, 69 (1), 15-20.

Bozinovic, F., Muñoz, J. L. P., Naya, D. E., \& Cruz-Neto, A. P. (2007). Adjusting energy expenditures to energy supply: food availability regulates torpor use and organ size in the Chilean mouse-opossum Thylamys elegans . Journal of Comparative Physiology B-Biochemical Systemic and Environmental Physiology, 177 (4), 393-400. doi:10.1007/s00360-006-0137-0

Brown, J. H., Gillooly, J. F., Allen, A. P., Savage, V. M., \& West, G. B. (2004). Toward a metabolic theory of ecology. Ecology, 85 (7), 1771-1789. doi:10.1890/03-9000

Buckley, L. B., Davies, T. J., Ackerly, D. D., Kraft, N. J. B., Harrison, S. P., Anacker, B. L., . . Wiens, J. J. (2010). Phylogeny, niche conservatism and the latitudinal diversity gradient in mammals.Proceedings of the Royal Society B-Biological Sciences, 277 (1691), 2131-2138. doi:10.1098/rspb.2010.0179

Bustamante, D. M., Nespolo, R. F., Rezende, E. L., \& Bozinovic, F. (2002). Dynamic thermal balance in the leaf-eared mouse: The interplay among ambient temperature, body size, and behavior. Physiological and Biochemical Zoology, 75 (4), 396-404. doi:10.1086/342253

Cáceres, N. C. (2002). Food habits and seed dispersal by the white-eared opossum, Didelphis albiventris , in Southern Brazil. Studies on Neotropical Fauna and Environment, 37 (2), 97-104. doi:10.1076/snfe.37.2.97.8582

Case, J. A., Goin, F. J., \& Woodburne, M. O. (2005). "South American" marsupials from the Late Cretaceous of North America and the origin of marsupial cohort. Journal of Mammalian Evolution, 12 (3-4), 461-494. doi:10.1007/s10914-005-7329-3

Celis-Diez, J. L., Hetz, J., Marín-Vial, P. A., Fuster, G., Necochea, P., Vásquez, R. A., . . Armesto, J. J. (2012). Population abundance, natural history, and habitat use by the arboreal marsupialDromiciops gliroides 
in rural Chiloé Island, Chile. Journal of Mammalogy, 93 (1), 134-148. doi:10.1644/10-MAMM-A-406.1

Charrier, R., Pinto, L., \& Rodríguez, P. (2006). Tectonostratigraphic evolution of the Andean Orogen in Chile. In T. Moreno \& W. Gibbons (Eds.), Geology of Chile (pp. 21-114). London: Geological Society of London.

Cortés, P. A., Franco, M., Moreno-Gómez, F. N., Barrientos, K., \& Nespolo, R. F. (2014). Thermoregulatory capacities and torpor in the South American marsupial, Dromiciops gliroides. Journal of Thermal Biology, 45, 1-8. doi:10.1016/j.jtherbio.2014.07.003

Cortés, P. A., Franco, M., Sabat, P., Quijano, S. A., \& Nespolo, R. F. (2011). Bioenergetics and intestinal phenotypic flexibility in the microbiotherid marsupial (Dromiciops gliroides) from the temperate forest in South America. Comparative Biochemistry and Physiology a-Molecular 8 Integrative Physiology, 160 (2), 117-124. doi:10.1016/j.cbpa.2011.05.014

D'Elía, G., Hurtado, N., \& D'Anatro, A. (2016). Alpha taxonomy ofDromiciops (Microbiotheriidae) with the description of 2 new species of monito del monte. Journal of Mammalogy, 97 (4), 1136-1152. doi:10.1093/jmammal/gyw068

Dennis, A. J. (2003). Scatter-hoarding by musky rat-kangaroos, Hypsiprymnodon moschatus , a tropical rainforest marsupial from Australia: implications for seed dispersal. Journal of Tropical Ecology, 19 , 619-627. doi:10.1017/S0266467403006023

di Virgilio, A., Amico, G. C., \& Morales, J. M. (2014). Behavioral traits of the arboreal marsupial Dromiciops gliroides during Tristerix corymbosus fruiting season. Journal of Mammalogy, 95 (6), 1189-1198. doi:10.1644/13-MAMM-A-281

Djawdan, M., \& Garland, T. (1988). Maximal running speeds of bipedal and quadrupedal rodents. Journal of Mammalogy, 69 (4), 765-772. doi:10.2307/1381631

Duchêne, D. A., Bragg, J. G., Duchêne, S., Neaves, L. E., Potter, S., Moritz, C., . . Eldridge, M. D. B. (2018). Analysis of phylogenomic tree space resolves relationships among marsupial families.Systematic Biology, 67 (3), 400-412. doi:10.1093/sysbio/syx076

Dungan, R. J., O'Cain, M. J., Lopez, M. L., \& Norton, D. A. (2002). Contribution by possums to seed rain and subsequent seed germination in successional vegetation, Canterbury, New Zealand. New Zealand Journal of Ecology, 26 (2), 121-127.

Ebensperger, L. A. (2001). A review of the evolutionary causes of rodent group-living. Acta Theriologica, 46 (2), 115-144. doi:10.1007/Bf03192423

Echeverría, C., Coomes, D., Salas, J., Rey-Benayas, J. M., Lara, A., \& Newton, A. (2006). Rapid deforestation and fragmentation of Chilean temperate forest. Biological Conservation, 130 (4), 481-494. doi:10.1016/j.biocon.2006.01.017

Echeverría, C., Newton, A., Lara, A., Rey-Benayas, J. M., \& Coomes, D. (2007). Impact of forest fragmentation on species composition and forest structure in the temperate landscape of southern Chile. Global Ecology and Biogeography, 16 , 426-439. doi:10.1111/j.1466-8238.2007.00311.x

Edelman, A. J., \& Koprowski, J. L. (2007). Communal nesting in asocial abert's squirrels: The role of social thermoregulation and breeding strategy. Ethology, 113 (2), 147-154. doi:10.1111/j.1439-0310.2006.01310.x

Eldridge, M. D. B., Beck, R. M. D., Croft, D. A., Travouillon, K. J., \& Fox, B. J. (2019). An emerging consensus in the evolution, phylogeny, and systematics of marsupials and their fossil relatives (Metatheria).Journal of Mammalogy, 100 (3), 802-837. doi:10.1093/jmammal/gyz018

Fisher, D. O., Owens, I. P. F., \& Johnson, C. N. (2001). The ecological basis of life history variation in marsupials. Ecology, 82 (12), 3531-3540. doi:10.1890/0012-9658(2001)082[3531:Tebolh]2.0.Co;2 
Fontúrbel, F. E. (2010). A methodological approach to assess the small mammal community diversity in the temperate rainforest of Patagonia.Mammalian Biology, 75 , 294-301. doi:10.1016/j.mambio.2009.03.012

Fontúrbel, F. E., Candia, A. B., \& Botto-Mahan, C. (2014). Nocturnal activity patterns of the monito del monte (Dromiciops gliroides ) in native and exotic habitats. Journal of Mammalogy, 95 (6), 1199-1206. doi:10.1644/13-MAMM-A-304

Fontúrbel, F. E., Candia, A. B., Salazar, D. A., Malebrán, J., González-Browne, C., \& Botto-Mahan, C. (2014). How forest marsupials are affected by habitat degradation and fragmentation? A metaanalysis.Naturwissenschaften, 101 (7), 599-602. doi:10.1007/s00114-014-1193-z

Fontúrbel, F. E., Franco, M., Rodríguez-Cabal, M. A., Rivarola, M. D., \& Amico, G. C. (2012). Ecological consistency across space: a synthesis of the ecological aspects of Dromiciops gliroides in Argentina and Chile. Naturwissenschaften, 99 , 873-881. doi:10.1007/s00114-012-0969-2

Fontúrbel, F. E., \& Jiménez, J. E. (2009). Underestimation of abundances of the Monito del Monte (Dromiciops gliroides ) due to a sampling artifact. Journal of Mammalogy, 90 (6), 1357-1362. doi:10.1644/09MAMM-A-027R1.1

Fontúrbel, F. E., \& Jiménez, J. E. (2011). Environmental and ecological architects: Guidelines for the Chilean temperate rainforest management derived from the monito del monte (Dromiciops gliroides ) conservation. Revista Chilena De Historia Natural, 84 (2), 203-211.

Fontúrbel, F. E., Lara, A., Lobos, D., \& Little, C. (2018). The cascade impacts of climate change could threaten key ecological interactions.Ecosphere, 9 (12), e02485. doi:10.1002/ecs2.2485

Fontúrbel, F. E., \& Medel, R. (2017). Frugivore-mediated selection in a habitat transformation scenario. Scientific Reports, 7 , 45371. doi:10.1038/srep45371

Fontúrbel, F. E., Salazar, D. A., \& Medel, R. (2017a). Increased resource availability prevents the disruption of key ecological interactions in disturbed habitats. [a]. Ecosphere, 8 (4), e01768. doi:10.1002/ecs2.1768

Fontúrbel, F. E., Salazar, D. A., \& Medel, R. (2017b). Why mistletoes are more aggregated in disturbed forests? The role of differential host mortality. [b]. Forest Ecology and Management, 394 , 13-19. doi:10.1016/j.foreco.2017.03.028

Fontúrbel, F. E., Silva-Rodríguez, E. A., Cárdenas, N. H., \& Jiménez, J. E. (2010). Spatial ecology of monito del monte (Dromiciops gliroides ) in a fragmented landscape of southern Chile. Mammalian Biology, 75 (1), 1-9. doi:10.1016/j.mambio.2009.08.004

Franco, M., Contreras, C., Cortes, P., Chappell, M. A., Soto-Gamboa, M., \& Nespolo, R. F. (2012). Aerobic power, huddling and the efficiency of torpor in the South American marsupial, Dromiciops gliroides .Biology Open, 1 (12), 1178-1184. doi:10.1242/bio.20122790

Franco, M., Contreras, C., \& Nespolo, R. F. (2013). Profound changes in blood parameters during torpor in a South American marsupial. Comparative Biochemistry and Physiology a-Molecular 83 Integrative Physiology, 166 (2), 338-342. doi:10.1016/j.cbpa.2013.07.010

Franco, M., Contreras, C., Place, N. J., Bozinovic, F., \& Nespolo, R. F. (2017). Leptin levels, seasonality and thermal acclimation in the Microbiotherid marsupial Dromiciops gliroides : Does photoperiod play a role? Comparative Biochemistry and Physiology a-Molecular 83 Integrative Physiology, 203 , 233-240. doi:10.1016/j.cbpa.2016.09.025

Franco, M., Quijano, A., \& Soto-Gamboa, M. (2011). Communal nesting, activity patterns, and population characteristics in the near-threatened monito del monte, Dromiciops gliroides. Journal of Mammalogy, 92 (5), 994-1004. doi:10.1644/10-Mamm-a-256.1

García, D., Rodríguez-Cabal, M. A., \& Amico, G. C. (2009). Seed dispersal by a frugivorous marsupial 
shapes the spatial scale of a mistletoe population. Journal of Ecology, 97 , 217-229. doi:10.1111/j.13652745.2008.01470.x

Geiser, F. (2013). Hibernation. Current Biology, 23 (5), R188-R193. doi:DOI 10.1016/j.cub.2013.01.062

Geiser, F., Currie, S. E., O'Shea, K. A., \& Hiebert, S. M. (2014). Torpor and hypothermia: reversed hysteresis of metabolic rate and body temperature. American Journal of Physiology-Regulatory Integrative and Comparative Physiology, 307 (11), R1324-R1329. doi:10.1152/ajpregu.00214.2014

Geiser, F., \& Ruf, T. (1995). Hibernation versus daily torpor in mammals and dirds - Physiological variables and classification of torpor patterns. Physiological Zoology, 68 (6), 935-966. doi:10.1086/physzool.68.6.30163788

Génin, F., \& Rambeloarivony, H. (2018). Mouse lemurs (Primates: Cheirogaleidae) cultivate green fruit gardens. Biological Journal of the Linnean Society, 124 (4), 607-620. doi:10.1093/biolinnean/bly087

Gilbert, C., McCafferty, D., Le Maho, Y., Martrette, J. M., Giroud, S., Blanc, S., \& Ancel, A. (2010). One for all and all for one: the energetic benefits of huddling in endotherms. Biological Reviews, 85 (3), 545-569. doi:10.1111/j.1469-185X.2009.00115.x

Godoy-Güinao, J., Díaz, I. A., \& Celis-Diez, J. L. (2018). Confirmation of arboreal habits in Dromiciops gliroides : a key role in Chilean Temperate Rainforests. Ecosphere, 9 (10), e02424. doi:10.1002/ecs2.2424

Goin, F. J., \& Abello, M. A. (2013). Los Metatheria sudamericanos de comienzos del Neógeno (Mioceno temprano, edad mamífero colhuehuapense): Microbiotheria y Polydolopimorphia. Ameghiniana, 50 (1), 5178. doi:10.5710/AMGH.9.11.2012.570

Goin, F. J., Zimicz, N., Reguero, M. A., Santillana, S. N., Marenssi, S. A., \& Moly, J. J. (2007). New Marsupial (Mammalia) from the Eocene of Antarctica, and the origins and affinities of the Microbiotheria.Revista de la Asociación Geológica Argentina, 62 , 597-603.

Gurovich, Y., \& Ashwell, K. W. S. (2020). Brain and behavior ofDromiciops gliroides . Journal of Mammalian Evolution, 27 (2), 177-197. doi:10.1007/s10914-018-09458-1

Habel, J. C., Assman, T., Schmidtt, T., \& Avise, J. C. (2010). Relict species: from past to future. In J. C. Habel \& T. Assman (Eds.), Relict Species. Phylogeography and Conservation Biology (pp. 1-5). Berlin: Springer.

Hamilton, M. J., Davidson, A. D., Sibly, R. M., \& Brown, J. H. (2011). Universal scaling of production rates across mammalian lineages.Proceedings of the Royal Society B-Biological Sciences, 278 (1705), 560-566. doi:10.1098/rspb.2010.1056

Harvey, P. H., Pagel, M. D., \& Rees, J. A. (1991). Mammalian metabolism and life histories. American Naturalist, 137 (4), 556-566. doi:10.1086/285183

Heldmaier, G., Ortmann, S., \& Elvert, R. (2004). Natural hypometabolism during hibernation and daily torpor in mammals. Respiratory Physiology \& Neurobiology, 141 (3), 317-329. doi:10.1016/j.resp.2004.03.014

Hershkovitz, P. (1999). Dromiciops gliroides Thomas, 1894, last of the Microbiotheria (Marsupialia), with a review of the family Microbiotheriidae. Fieldiana Zoology, 93 , 1-60.

Himes, C. M. T., Gallardo, M. H., \& Kenagy, G. J. (2008). Historical biogeography and post-glacial recolonization of South American temperate rain forest by the relictual marsupial Dromiciops gliroides .Journal of Biogeography, 35 (8), 1415-1424. doi:10.1111/j.1365-2699.2008.01895.x

Honorato, M. T., Altamirano, T. A., Ibarra, J. T., De la Maza, M., Bonacic, C., \& Martin, K. (2016). Composition and preferences regarding nest materials by cavity-nesting vertebrates in the Andean temperate forest of Chile. Bosque, 37 (3), 485-492. doi:10.4067/S0717-92002016000300005 
Humphries, M. M., Kramer, D. L., \& Thomas, D. W. (2003). The role of energy availability in mammalian hibernation: An experimental test in free-ranging eastern chipmunks. Physiological and Biochemical Zoology, 76 (2), 180-186. doi:10.1086/367949

Humphries, M. M., Thomas, D. W., \& Speakman, J. R. (2002). Climate-mediated energetic constraints on the distribution of hibernating mammals. Nature, 418 (6895), 313-316. doi:10.1038/nature00828

Iriarte, A. (2008). Mamíferos de Chile . Barcelona: Lynx Edicion.

Kelt, D. A., \& Martínez, D. R. (1989). Notes on distribution and ecology of two marsupials endemic to the Valdivian forests of southern South America. Journal of Mammalogy, 70 (1), 220-224. doi:10.2307/1381695

Kelt, D. A., Meserve, P. L., Patterson, B. D., \& Lang, B. K. (1999). Scale dependence and scale independence in habitat association of small mammals in southern temperate rainforest. Oikos, 85, 320-334.

Liu, B., Le, C. T., Barrett, R. L., Nickrent, D. L., Chen, Z. D., Lu, L. M., \& Vidal-Russell, R. (2018). Historical biogeography of Loranthaceae (Santalales): Diversification agrees with emergence of tropical forests and radiation of songbirds. Molecular Phylogenetics and Evolution, 124 , 199-212. doi:10.1016/j.ympev.2018.03.010

Lobos, G., Charrier, A., Carrasco, G., \& Palma, R. E. (2005). Presence of Dromiciops gliroides (Microbiotheria : Microbiotheriidae) in the deciduous forests of central Chile. Mammalian Biology, 70 (6), 376-380. doi:10.1016/j.mambio.2005.06.002

Long, J. A., Long, J. A., Archer, M., Flannery, T., \& Hand, S. (2002).Prehistoric mammals of Australia and New Guinea: one hundred million years of evolution : JHU Press.

Luo, Z. X., Yuan, C. X., Meng, Q. J., \& Ji, Q. (2011). A Jurassic eutherian mammal and divergence of marsupials and placentals. Nature, 476 (7361), 442-445. doi:10.1038/nature10291

Maldonado, K., Bozinovic, F., Newsome, S. D., \& Sabat, P. (2017). Testing the niche variation hypothesis in a community of passerine birds. Ecology, 98 (4), 903-908. doi:10.1002/ecy.1769

Maldonado, K., Sabat, P., Piriz, G., Bogdanovich, J. M., Nespolo, R. F., \& Bozinovic, F. (2016). Is maximum food intake in endotherms constrained by net or factorial aerobic scope? Lessons from the Leaf-Eared Mouse. Frontiers in Physiology, 7 , art649. doi:10.3389/fphys.2016.00649

Mann, G. (1978). Los pequeños mamíferos de Chile: marsupiales, quirópteros, edentados y roedores . Concepción: Editorial de la Universidad de Concepción.

Martin, G. M. (2010). Geographic distribution and historical occurrence of Dromiciops gliroides Thomas (Metatheria: Microbiotheria).Journal of Mammalogy, 91 (4), 1025-1035. doi:10.1644/09-MAMM-a-347.1

Martin, G. M. (2018). Variability and variation in DromiciopsThomas, 1894 (Marsupialia, Microbiotheria, Microbiotheriidae).Journal of Mammalogy, 99 (1), 159-173. doi:10.1093/jmammal/gyx175

Mathiasen, R. L., Nickrent, D. L., Shaw, D. C., \& Watson, D. M. (2008). Mistletoes: Pathology, systematics, ecology, and management. Plant Disease, 92 (7), 988-1006. doi:10.1094/Pdis-92-7-0988

Mejías, C., Castro-Pastene, C. A., Carrasco, H., Quintero-Galvis, J. F., Soto-Gamboa, M., Bozinovic, F., \& Nespolo, R. F. (2021). Natural history of the relict marsupial Monito del Monte at the most extreme altitudinal and latitudinal location. Ecosphere, 12 (6), e03577. doi:10.1002/ecs2.3577

Mejías, C., Sabat, P., Franco, L. M., Bozinovic, F., \& Nespolo, R. F. (2022). Body composition and energy savings by hibernation in the South American marsupial Dromiciops gliroides : a field study applying quantitative magnetic resonance. Physiological and Biochemical Zoology, in press.

Melvin, R. G., \& Andrews, M. T. (2009). Torpor induction in mammals: recent discoveries fueling new ideas. Trends in Endocrinology and Metabolism, 20 (10), 490-498. doi:10.1016/j.tem.2009.09.005 
Meredith, R. W., Westerman, M., Case, J. A., \& Springer, M. S. (2008). A Phylogeny and timescale for marsupial evolution based on sequences for five nuclear genes. Journal of Mammalian Evolution, 15 (1), 1-36. doi:10.1007/s10914-007-9062-6

Meserve, P. L. (1981). Trophic relationships among small mammals in a Chilean semiarid thorn scrub community. Journal of Mammalogy, 62 (2), 304-314.

Meserve, P. L., Lang, B. K., \& Patterson, B. D. (1988). Trophic relationships of small mammals in a Chilean temperate rainforest. Journal of Mammalogy, 69 (4), 721-730.

Mitchell, K. J., Pratt, R. C., Watson, L. N., Gibb, G. C., Llamas, B., Kasper, M., . . . Cooper, A. (2014). Molecular phylogeny, biogeography, and habitat preference Evolution of Marsupials. Molecular Biology and Evolution, 31 (9), 2322-2330. doi:10.1093/molbev/msu176

Mora, J. P., \& Soto-Gamboa, M. (2011). Legitimate seed dispersalUgni molinae Turcz. (Myrtaceae), by monito del monte,Dromiciops gliroides . Gayana Botanica, 68 (2), 309-312. doi:10.4067/S071766432011000200018

Muñoz-Pedreros, A., Lang, B. K., Bretos, M., \& Meserve, P. L. (2005). Reproduction and development of Dromiciops gliroides(Marsupialia: Microbiotheriidae) in temperate rainforests of Southern Chile. Gayana, 69 (2), 225-233.

Nespolo, R. F., Fontúrbel, F. E., Mejías, C., Gutiérrez, P., Contreras, R., Ruiz, J., . . Bozinovic, F. (2020). A mesocosm experiment in ecological physiology: adaptive modulation of energy budget in a hibernating marsupial under chronic caloric restriction. bioRxiv (preprint) , doi: 10.1101/2020.1106.1105.136028.

Nespolo, R. F., Fontúrbel, F. E., Mejías, C., Gutiérrez, P., Contreras, R., Ruiz, J., . . Bozinovic, F. (2021). A mesocosm experiment in ecological physiology: adaptive modulation of energy budget in a hibernating marsupial under chronic caloric restriction.Physiological and Biochemical Zoology, doi: 10.1086/717760.

Nespolo, R. F., Mejías, C., Espinoza, A., Quintero-Galvis, J. F., Rezende, E. L., Fontúrbel, F. E., \& Bozinovic, F. (2021). Heterothermy as the norm, homeothermy as the exception: variable torpor patterns in the South American marsupial monito del monte (Dromiciops gliroides ). Frontiers in Physiology, 12 , 682394. doi:10.3389/fphys.2021.682394

Nespolo, R. F., Saenz-Agudelo, P., Mejías, C., Quintero-Galvis, J. F., Peña, I., Sabat, P., . . Gurovich, Y. (2022). The physiological ecology of the enigmatic colocolo opossum, the monito del monte (genusDromiciops ) and its role as a bioindicator of the broadleaf biome. In M. L. Larramendy \& G. E. Liwszyc (Eds.), Marsupial and Placental Mammal Species in Environmental Risk Assessment Strategies . London UK: Royal Society of Chemistry.

Nespolo, R. F., Verdugo, C., Cortes, P. A., \& Bacigalupe, L. D. (2010). Bioenergetics of torpor in the Microbiotherid marsupial, Monito del Monte (Dromiciops gliroides ): the role of temperature and food availability. Journal of Comparative Physiology B-Biochemical Systemic and Environmental Physiology, 180 (5), 767-773. doi:10.1007/s00360-010-0449-y

Nickrent, D. L., Malécot, V., Vidal-Russell, R., \& Der, J. P. (2010). A revised classification of Santalales. Taxon, 59 (2), 538-558. doi:10.1002/tax.592019

Nilsson, M. A., Churakov, G., Sommer, M., Van Tran, N., Zemann, A., Brosius, J., \& Schmitz, J. (2010). Tracking marsupial evolution using archaic genomic retroposon insertions. Plos Biology, 8 (7), e1000436. doi:10.1371/journal.pbio.1000436

Norton, D. A., \& Carpenter, M. A. (1998). Mistletoes as parasites: host specificity and speciation. Trends in Ecology \& Evolution, 13 (3), 101-105. doi:10.1016/S0169-5347(97)01243-3

O’Leary, M. A., Bloch, J. I., Flynn, J. J., Gaudin, T. J., Giallombardo, A., Giannini, N. P., . . Cirranello, A. L. (2013). The placental mammal ancestor and the post-K-Pg radiation of placentals.Science, 339 (6120), 
662-667. doi:10.1126/science.1229237

Oda, E., Rodríguez-Gómez, G. B., Fontúrbel, F. E., Soto-Gamboa, M., \& Nespolo, R. F. (2019). Southernmost records of Dromiciops gliroides : extending its distribution beyond the Valdivian rainforest.Gayana, 83 , 145-149.

Olson, E. R., Carlson, M. R., Ramanujam, V. M. S., Sears, L., Anthony, S. E., Anich, P. S., . . Martin, J. G. (2021). Vivid biofluorescence discovered in the nocturnal Springhare (Pedetidae). Scientific Reports, 11 (1), 4125. doi:10.1038/s41598-021-83588-0

Patterson, B. D., Meserve, P. L., \& Lang, B. K. (1989). Distribution and abundance of small mammals along an elevational transect in temperate rainforest of Chile. Journal of Mammalogy, 70 (1), 67-78.

Pharo, E. A. (2019). Marsupial milk: a fluid source of nutrition and immune factors for the developing pouch young. Reproduction Fertility and Development, 31 (7), 1252-1265. doi:10.1071/Rd18197

Prevosti, F. J., Forasiepi, A., \& Zimicz, N. (2013). The evolution of the Cenozoic terrestrial mammalian predator guild in South America: Competition or replacement? Journal of Mammalian Evolution, 20 (1), 3-21. doi:10.1007/s10914-011-9175-9

Quijano, S. A. (2008). Uso y selección del hábitat del monito del monte, Dromiciops gliroides Thomas, 1894, en el bosque experimental San Martín, Centro-Sur de Chile. (PhD dissertation), Universidad Austral de Chile, Valdivia.

Quintero-Galvis, J. F., Saenz-Agudelo, P., Amico, G., Vazquez, M. S., Shafer, A. B. A., \& Nespolo, R. F. (2022). Population genomics reveal a complex and old speciation scenario of a relict marsupial lineage in South America. Molecular Phylogenetics and Evolution, in press.

Quintero-Galvis, J. F., Saenz-Agudelo, P., Celis-Diez, J. L., Amico, G. C., Vazquez, M. S., Shafer, A. B. A., \& Nespolo, R. F. (2021). The biogeography of Dromiciops in southern South America: Middle Miocene transgressions, speciation and associations withNothofagus. Molecular Phylogenetics and Evolution, 163 , 107234. doi:10.1016/j.ympev.2021.107234

Ramirez-Otarola, N., Narvaez, C., \& Sabat, P. (2011). Membrane-bound intestinal enzymes of passerine birds: dietary and phylogenetic correlates. Journal of Comparative Physiology B-Biochemical Systems and Environmental Physiology, 181 (6), 817-827. doi:10.1007/s00360-011-0557-3

Renfree, M. B. (1981). Marsupials - alternative mammals. Nature, 293 (5828), 100-101. doi:10.1038/293100a0

Restrepo, C., Sargent, S., Levey, D. J., \& Watson, D. M. (2002). The role of vertebrates in the diversification of New World mistletoes. In D. J. Levey, W. R. Silva, \& M. Galettí (Eds.), Seed Dispersal and Frugivory: Ecology, Evolution and Conservation (pp. 83-98). Wallingford, UK: CAB International.

Rodríguez-Cabal, M. A., Aizen, M. A., \& Novaro, A. J. (2007). Habitat fragmentation disrupts a plantdisperser mutualism in the temperate forest of South America. Biological Conservation, 139 (1), 195-202. doi:10.1016/j.biocon.2007.06.014

Rodriguez-Cabal, M. A., Amico, G. C., Novaro, A. J., \& Aizen, M. A. (2008). Population characteristics of Dromiciops gliroides (Philippi, 1893), an endemic marsupial of the temperate forest of Patagonia. Mammalian Biology, 73 (1), 74-76. doi:10.1016/j.mambio.2007.06.002

Rodríguez-Cabal, M. A., \& Branch, L. C. (2011). Influence of habitat factors on the distribution and abundance of a marsupial seed disperser. Journal of Mammalogy, 92 (6), 1245-1252. doi:10.1644/10-MAMM-A315.1

Roverud, R. C., \& Chappell, M. A. (1991). Energetic and thermoregulatory aspects of clustering behavior in the Neotropical batNoctilio albiventris . Physiological Zoology, 64 (6), 1527-1541. doi:10.1086/physzool.64.6.30158228 
Rubalcaba, J. G., Polo, V., Maia, R., Rubenstein, D. R., \& Veiga, J. P. (2016). Sexual and natural selection in the evolution of extended phenotypes: the use of green nesting material in starlings. Journal of Evolutionary Biology, 29 (8), 1585-1592. doi:10.1111/jeb.12893

Ruf, T., \& Geiser, F. (2015). Daily torpor and hibernation in birds and mammals. Biological Reviews, 90 (3), 891-926. doi:10.1111/brv.12137

Saavedra, B., \& Simonetti, J. A. (2001). New records ofDromiciops gliroides (Microbiotheria : Microbiotheriidae) andGeoxus valdivianus (Rodentia : Muridae) in central Chile: their implications for biogeography and conservation. Mammalia, 65 (1), 96-100.

Sabat, P., Lagos, J. A., \& Bozinovic, F. (1999). Test of the adaptive modulation hypothesis in rodents: dietary flexibility and enzyme plasticity. Comparative Biochemistry and Physiology a-Molecular and Integrative Physiology, 123 (1), 83-87. doi:10.1016/S1095-6433(99)00042-2

Sabat, P., Novoa, F., Bozinovic, F., \& del Rio, C. M. (1998). Dietary flexibility and intestinal plasticity in birds: A field and laboratory study. Physiological Zoology, 71 (2), 226-236. doi:10.1086/515905

Salazar, D. A., \& Fontúrbel, F. E. (2016). Beyond habitat structure: Landscape heterogeneity explains the monito del monte (Dromiciops gliroides) occurrence and behavior at habitats dominated by exotic trees. Integrative Zoology, 11 , 413-421. doi:10.1111/1749-4877.12198

Sanchez-Villagra, M. R. (2013). Why are there fewer marsupials than placentals? On the relevance of geography and physiology to evolutionary patterns of mammalian diversity and disparity. Journal of Mammalian Evolution, 20 (4), 279-290. doi:10.1007/s10914-012-9220-3

Santori, R. T., De Moraes, D. A., \& Cerqueira, R. (1995). Diet composition of Metachirus nudicaudatus and Didelphis aurita (Marsupialia, Didelphoidea) in southeastern Brazil.Mammalia, 59 (4), 511-516. doi:10.1515/mamm.1995.59.4.511

Santori, R. T., De Moraes, D. A., \& Cerqueira, R. (2004). Comparative gross morphology of the digestive tract in ten Didelphidae marsupial species. Mammalia, 68 (1), 27-36. doi:10.1515/mamm.2004.004

Schoener, T. W. (1971). Theory of feeding strategies. Annual Review of Ecology and Systematics, 2 , 369-404.

Schradin, C., Schubert, M., \& Pillay, N. (2006). Winter huddling groups in the striped mouse. Canadian Journal of Zoology, 84 (5), 693-698. doi:10.1139/Z06-048

Shattuck, M. R., \& Williams, S. A. (2010). Arboreality has allowed for the evolution of increased longevity in mammals. Proceedings of the National Academy of Sciences of the United States of America, 107 (10), 4635-4639. doi:10.1073/pnas.0911439107

Sibly, R. M., \& Calow, P. (1986). Physiological ecology of animals . London UK: Blackwell.

Sibly, R. M., \& Hone, J. (2002). Population growth rate and its determinants: an overview. Philosophical Transactions of the Royal Society B-Biological Sciences, 357 (1425), 1153-1170. doi:10.1098/rstb.2002.1117

Silva, S. I., Jaksic, F. A., \& Bozinovic, F. (2004). Interplay between metabolic rate and diet quality in the South American fox, Pseudalopex culpaeus . Comparative Biochemistry and Physiology a-Molecular $\mathcal{E}^{3}$ Integrative Physiology, 137 (1), 33-38. doi:10.1016/j.cbpb.2003.09.022

Suárez-Villota, E. Y., Quercia, C. A., Nuñez, J. J., Gallardo, M. H., Himes, C. M., \& Kenagy, G. J. (2018). Monotypic status of the South American relictual marsupial Dromiciops gliroides(Microbiotheria). Journal of Mammalogy, 99 (4), 803-812. doi:10.1093/jmammal/gyy073

Szalay, F. S. (1982). A new appraisal of marsupial phylogeny and classification: Carnivorous marsupials.

Tan, J. Q., Kelly, C. K., \& Jiang, L. (2013). Temporal niche promotes biodiversity during adaptive radiation. Nature Communications, 4 , a2102. doi:10.1038/ncomms3102 
Tejo, C. F., \& Fontúrbel, F. E. (2019). A vertical forest within the forest: millenary trees from the Valdivian rainforest as biodiversity hubs. Ecology, 100 (4), e02584. doi:10.1002/ecy.2584

Toien, O., Blake, J., Edgar, D. M., Grahn, D. A., Heller, H. C., \& Barnes, B. M. (2011). Hibernation in black bears: Independence of metabolic suppression from body temperature. Science, 331 (6019), 906-909. doi:10.1126/science.1199435

Torres-Contreras, H., \& Bozinovic, F. (1997). Food selection in an herbivorous rodent: Balancing nutrition with thermoregulation.Ecology, 78 (7), 2230-2237. doi:10.2307/2265958

Turbill, C., Bieber, C., \& Ruf, T. (2011). Hibernation is associated with increased survival and the evolution of slow life histories among mammals. Proceedings of the Royal Society B-Biological Sciences, 278 (1723), 3355-3363. doi:10.1098/rspb.2011.0190

Uribe, S. V., Chiappe, R. G., \& Estades, C. F. (2017). Persistence of Dromiciops gliroides in landscapes dominated by Pinus radiataplantations. Revista Chilena De Historia Natural, 90 , art2. doi:10.1186/s40693017-0065-2

Valladares-Gómez, A., Celis-Diez, J. L., Palma, R. E., \& Manríquez, G. S. (2017). Cranial morphological variation of Dromiciops gliroides (Microbiotheria) along its geographical distribution in south-central Chile: A three-dimensional analysis. Mammalian Biology, 87, 107-117. doi:10.1016/j.mambio.2017.07.003

Valladares-Gómez, A., Celis-Diez, J. L., Sepúlveda-Rodríguez, C., Inostroza-Michael, O., Hernández, C. E., \& Palma, R. E. (2019). Genetic diversity, population structure, and migration scenarios of the marsupial "Monito del Monte" in South-Central Chile. Journal of Heredity, 110 (6), 651-661. doi:10.1093/jhered/esz049

Vazquez, M. S., Rodríguez-Cabal, M. A., Gonzalez, D. V., Pacheco, G. S., \& Amico, G. C. (2018). Different nest predator guild associated with egg size in the Patagonian temperate forest. Bird Study, 65 (4), 478-483. doi:10.1080/00063657.2018.1555572

Vazquez, M. S., Zamora-Nasca, L. B., Rodriguez-Cabal, M. A., \& Amico, G. C. (2021). Interactive effects of habitat attributes and predator identity explain avian nest predation patterns. Emu-Austral Ornithology, 121 (3), 250-260. doi:10.1080/01584197.2021.1928519

Veloso, C., \& Bozinovic, F. (2000). Interplay between acclimation time and diet quality on basal metabolic rate in females of degus Octodon degus (Rodentia : Octodontidae). Journal of Zoology, 252 , 531-533. doi:10.1111/j.1469-7998.2000.tb01235.x

Viñals, A., Bertolino, S., \& Gil-Delgado, J. A. (2017). Communal nesting in the garden dormouse (Eliomys quercinus ).Behavioural Processes, 135 , 25-28. doi:10.1016/j.beproc.2016.11.016

Watson, D. M. (2020). Did mammals bring the first mistletoes into the tree-tops? American Naturalist, 196 (6), 769-774. doi:10.1086/711396

Watters, W. A., \& Fleming, C. A. (1972). Contributions to the Geology and Palaeontology of Chiloe Island, Southern Chile. Philosophical Transactions of the Royal Society of London. Series B, Biological Sciences, 263 (853), 369-408. doi:10.1098/rstb.1972.0004

Williams, P. A., Karl, B. J., Bannister, P., \& Lee, W. G. (2000). Small mammals as potential seed dispersers in New Zealand. Austral Ecology, 25 (5), 523-532. doi:10.1046/j.1442-9993.2000.01078.x

Wilson, W. A., O'Riain, M. J., Hetem, R. S., Fuller, A., \& Fick, L. G. (2010). Winter body temperature patterns in free-ranging Cape ground squirrel, Xerus inauris : no evidence for torpor. Journal of Comparative Physiology B-Biochemical Systemic and Environmental Physiology, 180 (7), 1099-1110. doi:10.1007/s00360010-0472-z

Woods, B. C. (2009). Using multivariate techniques to determine if yellow-bellied marmots feed selectively. Ethology Ecology 86 Evolution, 21 (3-4), 261-276. doi:10.1080/08927014.2009.9522481 
Yoder, J. B., Clancey, E., Des Roches, S., Eastman, J. M., Gentry, L., Godsoe, W., . . Harmon, L. J. (2010). Ecological opportunity and the origin of adaptive radiations. Journal of Evolutionary Biology, 23 (8), 1581-1596. doi:10.1111/j.1420-9101.2010.02029.x

\section{Figures}

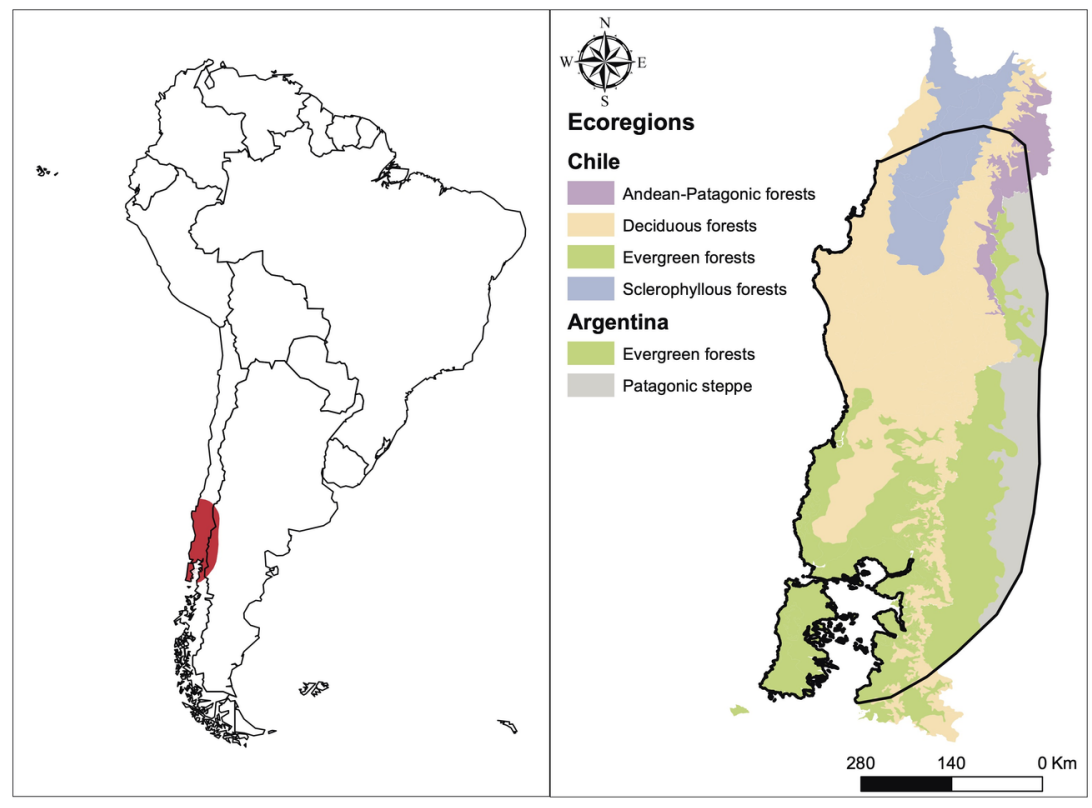

Figure 1. Updated Dromiciops gliroides distribution, including the new records extending the range to the South (based on Oda et al. 2019 and Mejías et al. 2021).

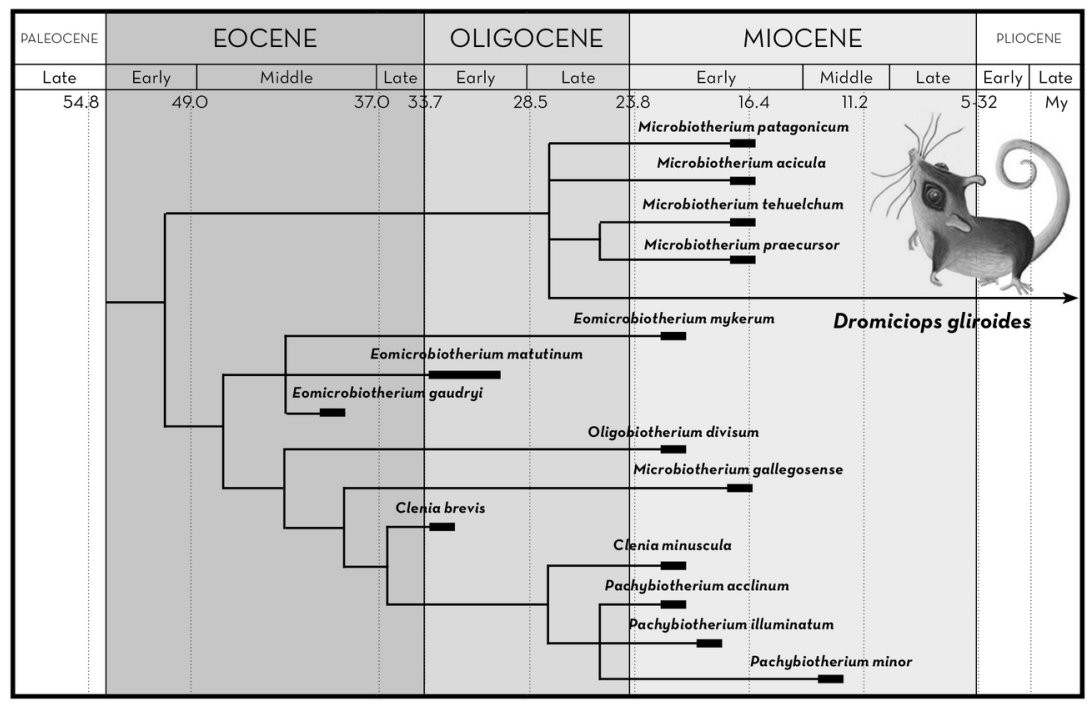

Figure 2. Calibrated fossil phylogeny of Microbiotheria modified from Goin and Abello (2013), show- 
ing the closeness of D. gliroides and Microbiotherium. According to these authors, bothDromiciops and Microbiotherium are morphologically indistinguishable.

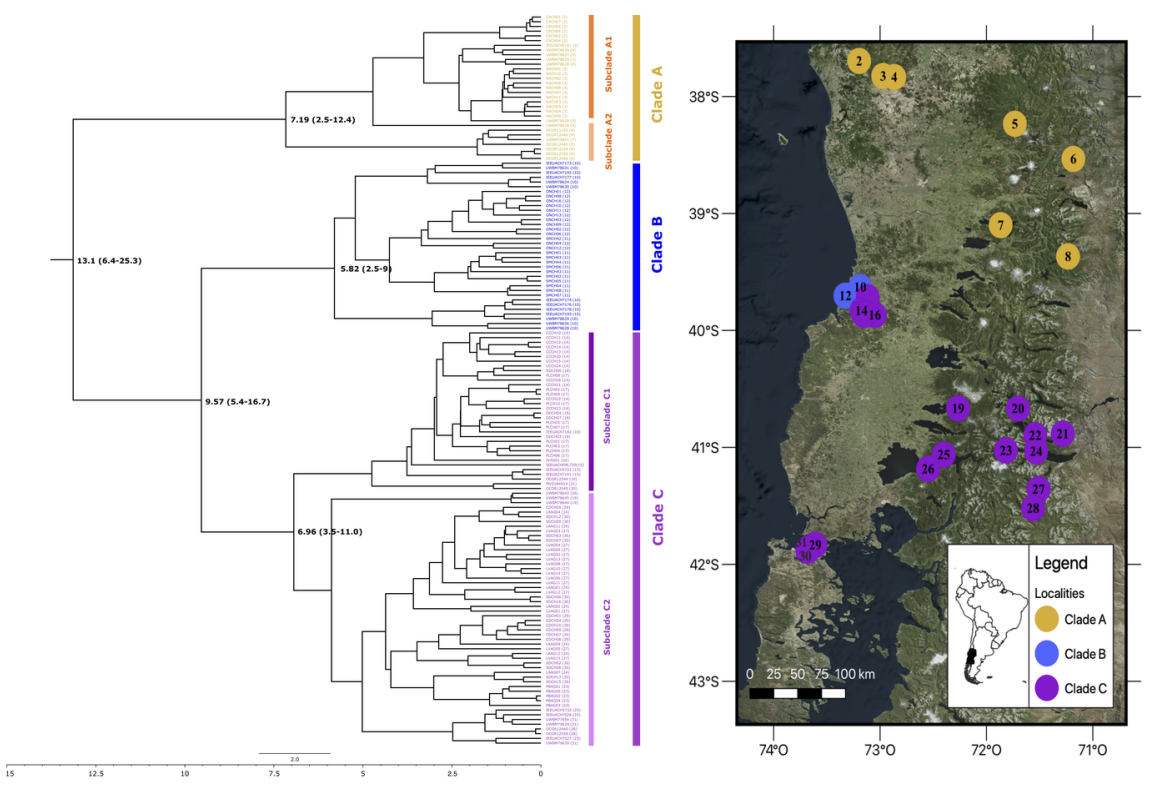

Figure 3. Dromiciops phylogenetic tree showing the support of two different species: Dromiciops bozinovici in the northern clade (A) and Dromiciops gliroides in the two southern clades (B and C). Colours show the correspondence of genetic distances and the locations in map. This figure was adapted from Quintero-Galvis et al. (2021).
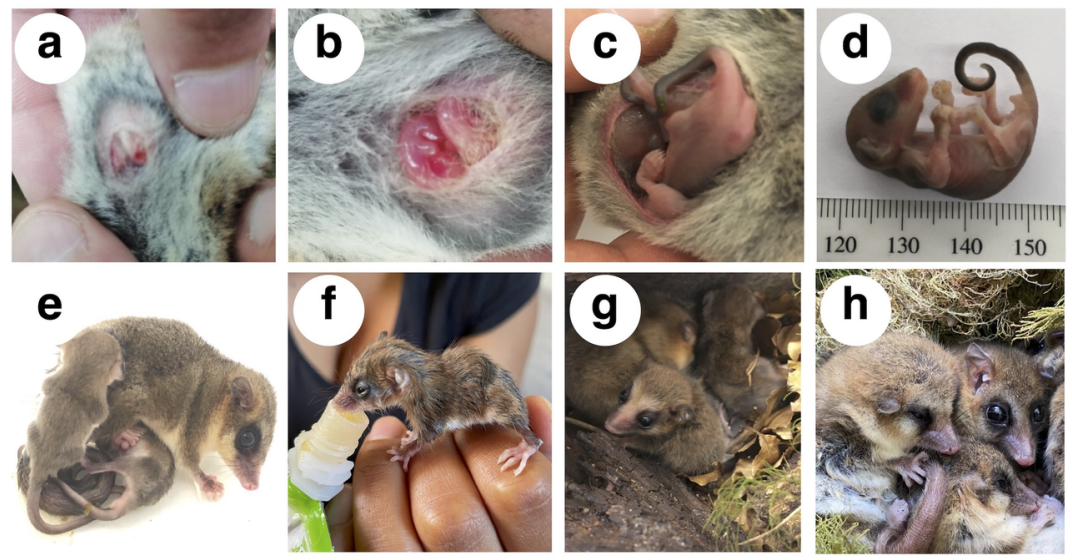

Figure 4. Dromiciops developmental stages. Panels $a$ and $b$ correspond to lactation in the pouch I, panels $c$ and $d$ correspond to lactation in the pouch II, panelse and $f$ correspond to lactation outside the pouch, panel $g$ correspond to juveniles, and panel $h$ correspond to adults. Photos: R. Nespolo. 


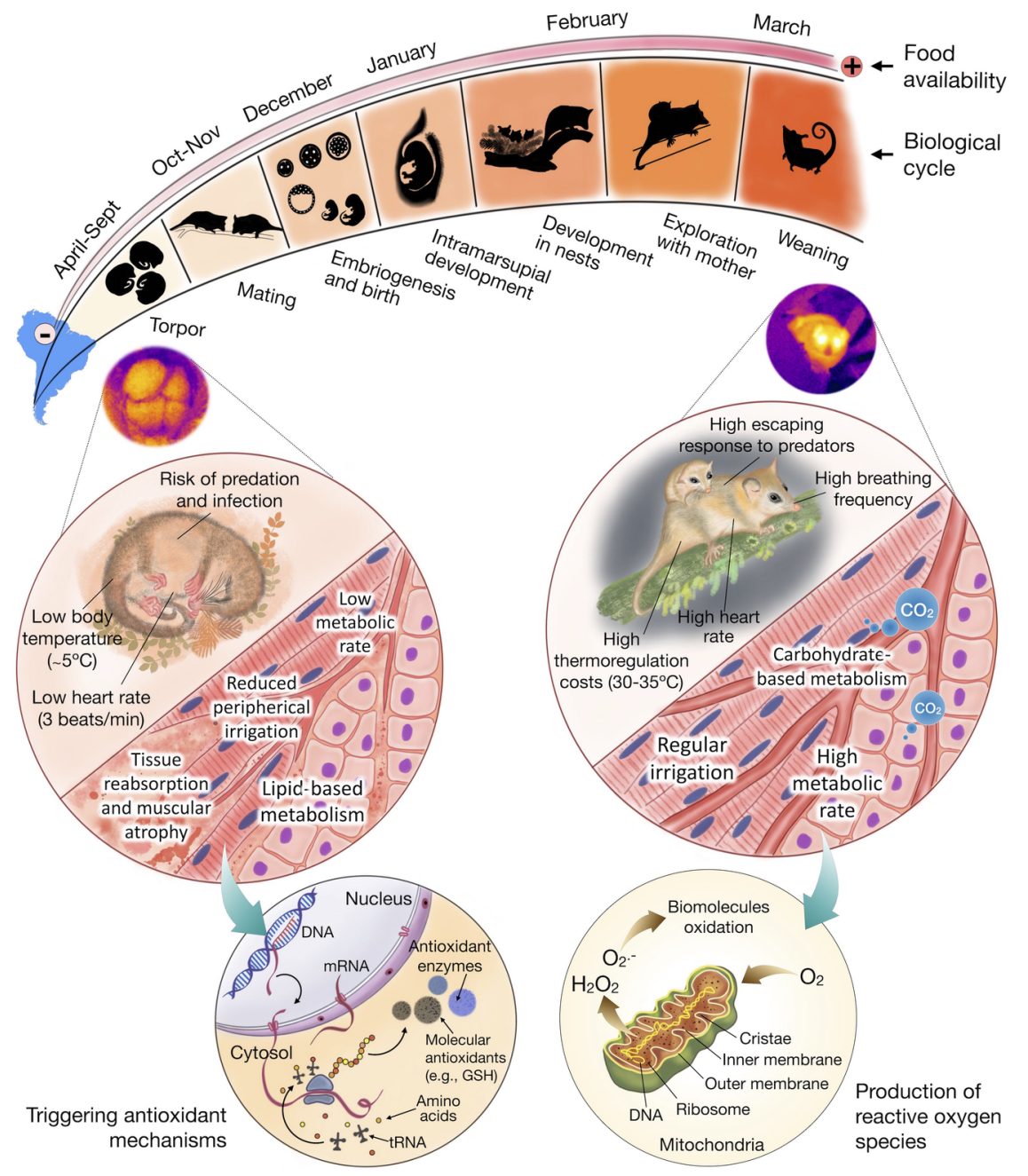

Figure 5. Annual cycle of Dromiciops gliroides showing its physiological, tissue, and biochemical changes during torpor and activity periods. Particular cellular alterations involve oxidative homeostasis by increasing molecular and enzymatic scavengers in torpor to inactivate reactive oxygen species generated during the activity period. The stages of the cycle were modified from Muñoz-Pedreros et al. (2005), according to a field experiment (Nespolo, Fontúrbel, et al., 2021). 


\section{- Net energy flux}

\section{Fat accumulation}

\section{--- Energy expenditure}

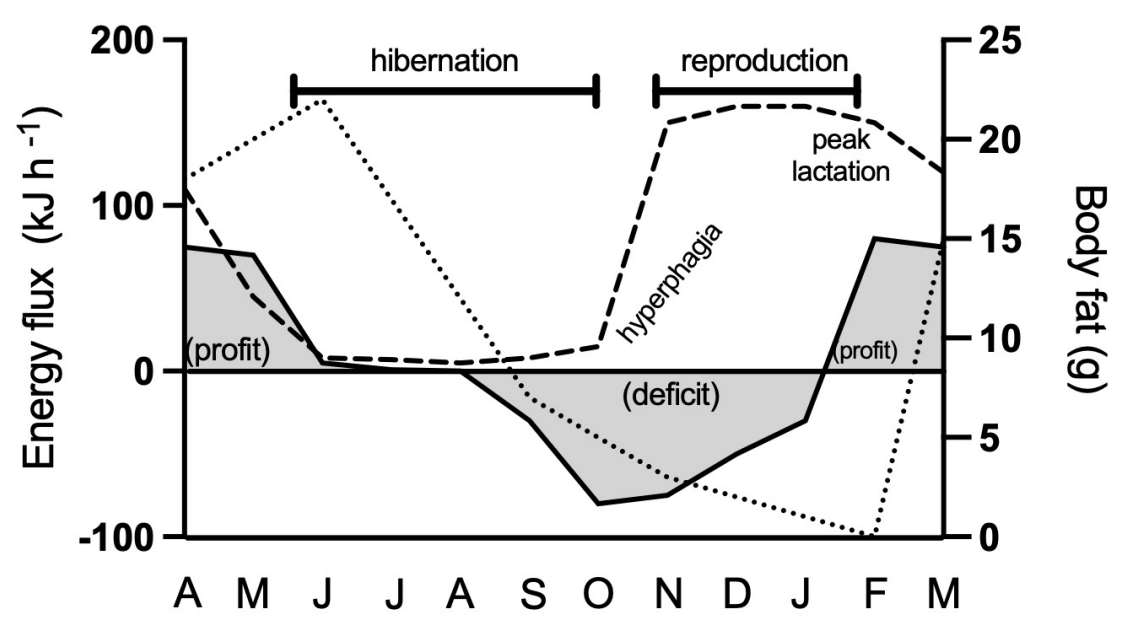

Figure 6. A hypothetical (but realistic) annual budget of energy and activity of a $M_{B}=40 \mathrm{~g}$ (lean mass)Dromiciops gliroides, summarized from descriptions of the reproductive cycle (Muñoz-Pedreros et al., 2005), seasonal variations in activity, adiposity, and body mass (Celis-Diez et al., 2012; Franco et al., 2017) and food availability (di Virgilio et al., 2014; Franco et al., 2011; Quijano, 2008). After reproduction, D. gliroidesreduce activity and energy expenditure and accumulate almost twice their body size in fat (Franco et al., 2017). Fat accumulation was estimated from body mass fluctuations using quantitative magnetic resonance, which indicated that animals could double their body mass in autumn (Mejías et al., 2022). 


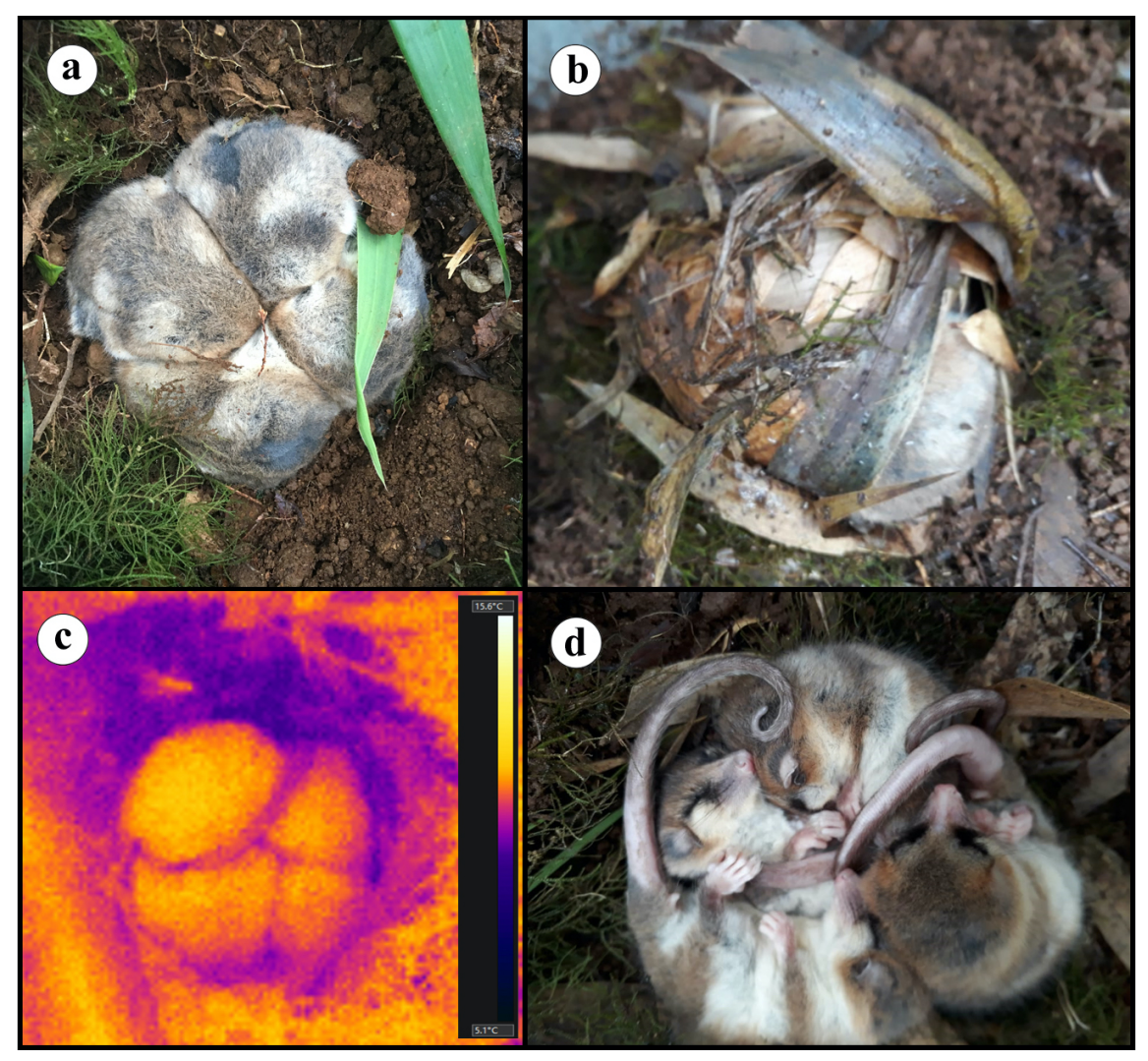

Figure 7. Photos of hibernating D. gliroides taken from an outdoor facility near Valdivia in May (austral autumn). (a) Four clustered individuals packed to minimise heat loss in a nest (uncovered). (b) a single individual within a typical nest built on bamboo (Chusquea quila) leaves and mosses. (c) A thermography of four clustered individuals showing their body temperature $\left({ }^{\sim} 10^{\circ} \mathrm{C}\right.$, according to the colour bar scale to the right). Ambient temperature is $5.2^{\circ} \mathrm{C}$. (d) Lateral view of hibernating individuals. Photo credits: panel (a): R. Nespolo, panel (b): C. Mejias, panel (c): E. Oda, panel (d): P. Gutiérrez. 